\title{
Windows of opportunity for catching up in formative clean-tech sectors and the rise of China in concentrated solar power
}

\section{CCEP Working Paper 2104 March 2021}

\section{Jorrit Gosens}

Crawford School of Public Policy, Australian National University

\section{Alina Gilmanova}

Key Laboratory of Solar Thermal Energy and Photovoltaic Systems, Institute for Electrical Engineering, Chinese Academy of Sciences

\section{Johan Lilliestam}

Institute for Advanced Sustainability Studies (IASS)

\begin{abstract}
We analyse the potential for industry entry and catching up by latecomer countries or firms in formative sectors, by deriving a framework that builds on the concept of windows of opportunity for catching up. This framework highlights differences in technological, market, and institutional characteristics between formative and mature sectors, and elaborates how this may affect opportunities for catching up. We apply this framework to the global Concentrated Solar Power sector, in which China has rapidly narrowed the gap to the global forefront in terms of technological capabilities and market competitiveness. We find that the formative nature of the sector resulted in turbulent development of the technological, market, and institutional dimensions, making it more difficult for early leaders to retain leadership, and therefore easier for latecomer firms or countries to catch up. This signals an increased role in early-stage technology development in the next phase of the energy transition.
\end{abstract}




\section{Keywords:}

Catching up; windows of opportunity; formative sectors; concentrating solar power; China

\section{JEL Classification:}

\section{Suggested Citation:}

Gosens, J.,Gilmanova, A. and Lilliestam, J. (2021), Windows of opportunity for catching up in formative clean-tech sectors and the rise of China in concentrated solar power, Working Paper 21-04, Mar 2021, Centre for Climate and Energy Policy, Crawford School of Public Policy, The Australian National University.

\section{Address for Correspondence:}

Jorrit Gosens. Crawford School of Public Policy, Australian National University, 132 Lennox Crossing, Acton ACT 2601, Australia. Jorrit.gosens@anu.edu.au

The Centre for Climate Economics and Policy is a research unit at the Crawford School of Public Policy at the Australian National University. The working paper series is intended to facilitate academic and policy discussion. The views expressed in working papers are those of the authors. 


\section{Introduction}

A global transition is underway towards more sustainable systems of production and consumption. This transition process is particularly visible in energy systems, where modern renewables, chiefly wind power and solar PV, accounted for circa $10 \%$ of global power production in 2020 (Ember Climate, 2020). The manufacturing industries for these technologies have become substantial engines of economic growth, with investment in wind and PV averaging roughly $\$ 300$ billion per year between 2015 and 2020 (BNEF, 2021). The transition is likely to continue accelerating, as the number of countries with net-zero emission targets keeps growing, and the global economy truly seems to be shifting to a new 'technoeconomic paradigm', of a greening of industry (Mathews, 2013).

Different strands of literature, including those on deep decarbonisation (Geels et al., 2017), transformative change (Grin et al., 2010), mission innovation (Mazzucato, 2018), and green industry policy (Rodrik, 2014), have all stressed that the transition will require substantial investment in R\&D, deliberative policy making, and cultivation of societal support, amongst others. Each of these perspectives find that transformations towards environmental sustainability would not have to harm economic growth, but rather that the sectors associated with these transitions may offer new economic growth opportunities. For latecomer countries, which have a stronger development imperative, the evidence increasingly shows that economic co-benefits of an early transition to green industries outweigh those of growth strategies that would lock them in to conventional, , technologies (Berkhout et al., 2010; Pegels and Altenburg, 2020).

There is, however, a wide range of different clean-tech, including a variety of different renewable energy technologies. This includes the (more) mature technologies of hydropower, biomass power, wind power and solar PV, but also a number of other renewable energy technologies, such as tidal \& wave power, enhanced geothermal, thin film, perovskite and organic PV, and concentrated solar power, which are still in formative stages of development, but may come to support, or compete with, more mature renewable energy technologies in the future (Hussain et al., 2017). Not all countries will be equally well positioned to develop each of these technologies and their related manufacturing industries, and effective green industry policy therefore likely has to consider both country and technological specificities when selecting technologies and sectors to focus support on.

For example, it is well established that countries, and similarly regions or firms, have better potential to diversify into sectors that are more closely related to existing competencies (Boschma et al., 2017; Boschma and Capone, 2015). The formation of innovation systems may 
depend on highly technology-specific system building resources, including competencies but also market demand, capital supply, and other resources, that are available or abundant only in specific locales (Andersson et al., 2018). With regards to the opportunity set for industry formation available to advanced versus latecomer economies, a recently developing strand on technological characteristics has posited that industries with less complexity, innovation modes based on codified scientific knowledge, and mass-produced, commoditized products, may most readily see strong shifts of manufacturing industries towards latecomers (Binz and Truffer, 2017; Huenteler et al., 2016; Schmidt and Huenteler, 2016).

While this literature has refined the evidence on how manufacturing industries for different technologies may be subject to spatial shifts, it largely reiterates the notion that for latecomer countries, opportunities exist primarily, or are limited to, later stages in an industry life-cycle (Anderson and Tushman, 1990). Simultaneously, a growing body of evidence shows that increasingly capable emerging and developing economies are more involved in earlystage technology development than has traditionally been recognized (Berkhout et al., 2010; Binz et al., 2020, 2012; Gosens et al., 2020; Quitzow, 2015; Sengers and Raven, 2015; Tyfield et al., 2015). This literature currently still lacks a clear exposition of the ways in which formative or mature sectors may provide stronger or weaker entry barriers for latecomers.

Here, we contribute to discussions on what type of industries may be suitable targets for green growth policies for latecomer countries, by investigating how the formative nature of a sector affects the potential for industry entry and catching up.

To answer this question, we develop a framework building on the notion of 'windows of opportunity for catching up' (Lee and Malerba, 2017; Perez and Soete, 1988), in order to 1) clarify how differences in the technological, market, and institutional characteristics between formative and mature sectors affect the types of windows of opportunity that may appear, and 2) how those differences affect the potential for industry entry and catching up by latecomer firms or countries. We show the relevance of this framework by applying it to a case study of how China has caught up in the concentrated solar power (CSP) sector.

We find that the development of technologies, markets, and institutions in formative sectors tends to be more turbulent in formative sectors than in mature sectors, creating an environment that makes it difficult for early leaders to retain leadership. Empirically, we find that China is rapidly closing the gap to the global forefront in the CSP sector, and that this high pace of catch-up is largely due to the formative nature of technological, market, and institutional dimensions of the global CSP sector. Further, the formative phase of the CSP 
sector saw a concurrent mix of a number of different windows of opportunity in technological, market, and institutional dimensions, that opened up within the span of a few years, adding to the difficulty to retain leadership, and therefore improving the potential for latecomers to catch up. Early entry into such formative sectors therefore deserves consideration when emerging economy governments select focus-sectors in green industry policy, in particular for countries with certain minimum levels of domestic capability formation.

\section{Opportunities for catching up in formative and mature clean-tech sectors}

In the study of sustainability transitions, the distinction between formative versus mature technologies or sectors is mostly used in reference to the relative development status of sustainable versus conventional technological alternatives. The literature on transitions studies, Technological Innovation Systems (TIS), and related strands, have highlighted how existing socio-technical regimes, including elements such as infrastructure, market design, and user practices, are all designed around and reinforce the relative competitiveness of the conventional, incumbent technology (Geels, 2002; Hekkert et al., 2007). Supporting the development of the sustainable alternative requires a sustained policy making efforts, including substantial investment in early stage R\&D, supported market creation with e.g., feed-in tariffs, and other financial and regulatory support mechanisms, to disentangle the existing socio-technical regime and reconstruct it around the novel technology (Bergek et al., 2008; Schot and Geels, 2008). The observed variation in the successfulness of different countries to develop and deploy certain novel technological alternatives, is often explained through different policy strategies and policy instrument selection (Garud and Karnøe, 2003; Hillman et al., 2008; Vasseur et al., 2013).

With regards to the relative role of country groups with different economic development status in global sustainability transitions, this literature has most often reiterated lessons from traditional catching-up literature, that the entry of challengers from latecomer countries is usually preceded by the establishment of a dominant design, when there is a shift from product to process innovation and more commoditized market demand, which are considered to better match with latecomer competencies (Abernathy and Utterback, 1978; Bento et al., 2018; Binz et al., 2017a; Perez and Soete, 1988). This is largely based on the observation that the wind turbine and PV panel industries initially started out as highly localized experiments, supplying niche markets, in advanced economy countries (Dewald and Truffer, 2011; Garud and Karnøe, 2003). Only decades after their initial R\&D stages, did markets and manufacturing activities see widespread global diffusion, in particular to large emerging economies (Binz et al., 2017b; Lewis, 2011). Explanations of why specific 
latecomer countries were or were not successful in deploying these technologies and in developing domestic industries for these technologies again largely focused on differences in policy strategies, although more focused on the relative success of accessing and utilizing global knowledge pools and other innovation system building resources (de la Tour et al., 2011; Gosens et al., 2014; Lewis, 2011). This literature has further recognized that successful catching-up will require specific policy mixes for technologically distinct industry types (Binz et al., 2017a).

Despite the central role of policy in both innovation system formation and catchingup literatures, there is simultaneously the recognition that the types of technologies and industries that a country may develop, and their roles in the development process that a country can fulfill, are co-determined by a (mis)match of country characteristics and technological specificities (Huenteler et al., 2016; Malerba and Nelson, 2011; Schmidt and Huenteler, 2016).

The traditional catching-up literature already considered that country characteristics, particularly the low levels of technological capabilities, limited the involvement of latecomer countries and firms in early-stage technological development processes (Lee and Lim, 2001; Morrison et al., 2008). However, this general rule may be losing traction, as a number of key emerging economies are increasingly contributing to global basic research output (Xie et al., 2014) and are involved in increasingly complex manufacturing processes (Surana et al., 2020). There is further increasing evidence that factors entirely exogenous to the country, specifically technological or sectoral characteristics, co-determine the likelihood and pace of catching up. This includes the complexity of the design and the scale of the production process (Schmidt and Huenteler, 2016), innovation modes that are based on either learning by doing, using, and interacting (DUI) or more codified scientific knowledge (STI), and different types of product valuation systems (Binz and Truffer, 2017), or sectors that experience different patterns of evolution (Lee and Malerba, 2017; Malerba and Nelson, 2011). A factor that remains underspecified in this literature is how the formative or mature nature of a sector influences catching up in a world where technological capability gaps between advanced and emerging economies are narrowing, and competition is ongoing in a range of novel renewable energy technologies.

In order to compare the relative opportunities available to latecomer economies and firms in formative versus mature clean-tech sectors, we require a framework with analytical categories that are applicable throughout a sectors' lifecycle. For this purpose, we build on the framework of 'windows of opportunity' for catching-up. Perez and Soete (1988) originally 
used the concept to refer to the rise of new techno-economic paradigms, which may cause the incumbents competencies to become obsolete, and narrow the competency gap between latecomers and incumbents. Recently, Lee and Malerba (2017) have expanded this to discontinuities in the technological, demand, and institutional dimensions of a sector. Whilst this framework is rooted in Sectoral Innovation Systems literature, which has traditionally been applied predominantly to more mature sectors (e.g., Malerba and Nelson, 2011), the dimensions of technology, demand, and institutions are building blocks that are present, yet differently manifested, in sectors at differing maturity, and may therefore similarly be applied to study catch-up dynamics in early industry lifecycle stages (cf. Binz et al., 2020; Yap and Truffer, 2019).

Here, we use these dimensions to categorize insights from strands of literature that go into both mature and formative sector specifics, including catching up, lead markets, and technological innovation systems. We re-interpret this literature in terms of implications for the differences that exist between formative and mature sectors, and how this results in different types of windows of opportunity. We further build on those differences to hypothesize how these may influence opportunities for catching up by latecomers in formative versus mature clean-tech sectors. Importantly, this sets the scope of our analysis; the factors included in our framework must both 1 ) result in different windows of opportunity due to differences in formative versus mature sectors, and 2 ) be expected to result in a different potential for catching up. We detail these differences for each of the technological, market, and institutional dimensions, in sections 2.1 through 2.3. A summary of the differences and the hypothesized relevance for opportunities for catching-up is provided in Table 1.

We note here that many previous frameworks differentiate between formative and mature sectors, but few provide a strict boundary between the two (a recent exception is Bento and Wilson (2016)). We consider a sector to be formative when e.g., considerable competition between technological alternatives is still ongoing, levels of market uptake remain very low, and institutions remain to be formalized, etc. (Anderson and Tushman, 1990; Utterback and Abernathy, 1975); more explanation is provided in subsections 2.1-2.3 and Table 1.

Further, our framework and empirical results considers catching up as the process of latecomers closing in on global leaders in terms of both technological capabilities and market 
shares. The latter is more easily measured, and much more often used as a key numeric indicator of catching up (Lee and Malerba, 2017). Technological capabilities can be a driver of market competitiveness, but we acknowledge that growth in market shares is not necessarily due to strong domestic capability formation (Lee and Lim, 2001).

Lastly, we use the term 'early leaders' to label the competitors met by challengers from latecomer countries when entering formative sectors, to differentiate these with more established 'incumbents' in mature sectors.

2.1. Technological windows of opportunity in mature and formative sectors

\subsubsection{Stocks of experience}

In mature sectors, latecomers face competition with incumbents that have built up a considerable stock of experience, which can be both a blessing and a curse. On the one hand, there is an 'advantage of backwardness', as latecomer countries may access and utilize global pools of knowledge, which is considered to be a more effective and quicker route in spurring upgrading of domestic industries than relying solely on domestic development processes (Gerschenkron, 1962). Much of the catch-up literature has therefore focused on mechanisms through which such global knowledge may be accessed and absorbed (Abramovitz, 1986; Lee et al., 1988). On the other hand, the existing stocks of experience held by incumbent industry leaders enable them to push technological progress and develop the next generation of a technology, whilst latecomers are still in the process of developing capabilities for current generations (Abramovitz, 1986; Perez and Soete, 1988; Tushman and Anderson, 1986). Latecomers in the wind power sector, for example, have long trailed early leaders in the size of turbines they were able to manufacture (Gosens and Lu, 2013).

In formative sectors, early leaders will hold more limited stocks of experience, and latecomers will therefore face a smaller experience gap, which makes catching up easier. However, possibilities for typical latecomer mechanisms for obtaining competencies, such as licensing, mergers \& acquisitions, inclusion in global value chains, or the purchase of turn-key production lines, are smaller in formative sectors (Gereffi et al., 2001; Reddy and Zhao, 1990). 


\subsubsection{Dominant designs}

At some point in the industry life-cycle, the direction of technological improvements become focused on a single, dominant design, around which leading firms start to build up their competencies (Abernathy and Clark, 1985; Abernathy and Utterback, 1978). A technological window of opportunity may arise in case of a radical technological discontinuity that disrupts or makes competencies for the existing dominant design obsolete (Abernathy and Clark, 1985; Lee and Malerba, 2017; Perez and Soete, 1988). A classic example is the shift from analogue to digital technologies in e.g., television or camera industries (Lee et al., 2005). The equivalent in the energy sector is the switch from fossil-fuel to renewable energy technologies: competency in coal-fired boilers is no advantage in the wind or PV industry. The relevance of the technological shift to latecomers can be seen in the early dominance of 'pureplay' firms in the wind and PV sectors, whilst energy sector incumbents such as GE or Siemens entered the wind power sector only after the technology and markets had firmly been established (Garud and Karnøe, 2003; Lewis and Wiser, 2007). Incumbents may be sceptical of the potential of the new technology, and delay investment in the competencies and production facilities required for it, in particular when the current product portfolio remains profitable, and when supporting growth of the new technology may even reduce profitability of that current portfolio (Chandy and Tellis, 2000; Nelson and Winter, 1982).

In formative sectors, a dominant design is yet to be established, and individual firms or countries do not yet have entrenched competencies. Technological pathways in formative sectors arise only after a lengthy process of creation and selection of a multitude of competing designs, each of which may demand different competencies (Abernathy and Utterback, 1978; Schot and Geels, 2008). Such a process has similarly disruptive effects on the build-up of competencies as developments in so-called short-cycle technologies, where different generations of technology follow each other in quick succession. Such sectors have been identified as challenging environments for incumbents to maintain competency leads, and thus hold more potential for latecomers to attain leadership positions (Lee, 2005).

2.2. Market demand windows of opportunity in mature and formative sectors 2.2.1. Market preferences for technological alternatives

As sectors mature, market demand typically becomes either more commoditized or sub-divided in specific market-segments with well-defined consumer preferences (Binz and Truffer, 2017; Huenteler et al., 2016). Market windows of opportunity can open when there is a sudden shift or the rise of new demand, which incumbents, satisfied with their success in current markets, fail to respond to, leaving room for latecomers to serve those markets 
(Chandy and Tellis, 2000). Shifts in demand are often closely related to technological shifts, as different consumers preferences may be better met with different technological alternatives. Examples include demand shifting from analogue to digital cameras, or the growth of demand for mid-sized jet airplanes with growing demand for shorter distance air travel (Vértesy, 2017).

In formative sectors, where technological shifts are more likely and may occur more often, such demand shifts are even more relevant. An illustrative example is the shift towards sustainable mobility, where several technological alternatives (sugar- or starch-based biofuels, cellulosic biofuels, hybrid and fully battery electric, hydrogen and fuel cell cars, and others) have all been competing for this newly created market demand, with repeated shifts in expectations about the most viable alternative. The technologies involved in each of these pathways require different competencies and manufacturing facilities, and no single firm, even car industry incumbents with vast stocks of experience and capital, is capable to invest in each of them. The typical boom and bust in expectations, or hype-cycles, about formative sector growth (van Lente et al., 2013), may exacerbate the incumbents' hesitance to invest, whilst buoying the eagerness to invest by hopeful latecomers. Once market demand truly increases, the firms with early investments in the favoured alternative will be well placed to serve the growing market, and thus create opportunities for firms from latecomer countries to capture market shares.

\subsubsection{Geographical development of market demand}

Mature sectors may see geographic shifts in demand, when traditional industries find new demand in countries with growing affluence or different consumer preferences, but the potential for latecomer challengers to capture such new markets may be limited (Morrison and Rabellotti, 2017). The traditional view on breaking in to international markets by firms from latecomer countries is that it requires a period of protected domestic markets, to stave off foreign competition and allow domestic firms to grow competencies, before they would viably manage to compete internationally (Hoekman et al., 2005; Lee and Lim, 2001).

In formative sectors, such geographic spread is of even greater significance as early nurturing markets tend to be highly localized phenomena, whilst growth phases are often associated with internationalizing markets (Beise and Rennings, 2005; Kemp et al., 1998). In such sectors, domestic 'nurturing' is important to create 'lead markets' that may spur later success in export markets by, amongst others, providing an environment for user-producer interactions that help improve product specifications (Beise and Rennings, 2005). The different timing of entry into export markets matters as well, as capturing shares of formative global markets might not require pushing out established foreign competitors. Others have 
cast doubt on the opportunities and requirements of domestic nurturing markets, with increasing prevalence of 'born global' challengers (Rialp et al., 2005), possibly conditioned by differing levels of customization or commodification of demand preferences in different sectors (Binz and Truffer, 2017).

\subsubsection{Temporal development of market demand}

Mature sectors may see cyclical patterns of rising and falling demand (growth), driven e.g., by macro-economic cycles or by expanding or retracting areas of application of a product. Mathews (Mathews, 2005) concluded that upturns consolidate the position of incumbents, whilst downturns create openings for industry entry by latecomers.

In formative sectors, demand growth patterns typically follow logistic growth patterns, with a lengthy 'era of ferment' with limited demand, followed by an exponential growth phase, and subsequently plateauing growth (Bento et al., 2018; Marchetti and Nakićenović, 1979). The era of ferment may prove a difficult environment for early leaders to sustain operations and retain leadership. Activity may be limited to small numbers of pilot and demonstration projects, and the volume of demand and related revenue may fluctuate wildly (Bergek et al., 2008; Kemp et al., 1998). The rapid growth phase of a niche market presents difficulties as well, as it is very difficult to forecast and plan for exponential growth. Too conservative investment in production capacity means that market demand will go unmet, allowing latecomer challengers to fill in the gap. Too optimistic investment creates over-capacity that will remain idle, putting a strain on company finances. To illustrate the challenge of predicting such growth, annual global growth rates of wind power installations fluctuated between 0 and $55 \%$ in 2000-2015 and between -5 and $150 \%$ for solar PV (BP, 2018). In contrast with the evidence provided by Mathews (Mathews, 2005), the rapid growth phases in both wind and PV precipitated high levels of industry entry and successful capture of market share by latecomers, whilst plateauing growth led to industry shake-outs, including of recent market entrants (Binz and Anadon, 2018; Gosens and Lu, 2013).

2.3. Institutional windows of opportunity in mature and formative sectors

\subsubsection{Government interventions}

In both mature and formative sectors, governments may create environments that benefit domestic over foreign firms with interventions such as R\&D programs, support schemes, or the creation of market entry barriers (Malerba and Nelson, 2011). These types of intervention to promote the competitive strength of latecomer versus incumbent firms are very similar to the interventions suggested in promoting the competitive strength of novel 
clean-tech versus conventional technologies (Bergek et al., 2008; Kemp et al., 1998). Countries with appropriate institutional conditions, such as the strong government bureaucracies and government-industry coordination seen in 'Asian development states', may therefore be better positioned to compete in the growth sectors associated with the global transition to a green techno-economic paradigm (Angel and Rock, 2009; Mathews, 2013).

Whilst government interventions themselves are not an exogenous factor, the sectoral development stage is, and this is likely to influence the impact that such policies may have. In formative sectors, a national government R\&D program may represent a much more substantial share of global R\&D efforts when compared with volumes of government and corporate R\&D in established sectors. Similarly, the creation of a (protected) domestic market may provide a far larger share of global market demand than in a mature sector, with equally more substantial benefits to domestic industry versus foreign early leaders. Substantial government interference in formative sectors is further less likely to result in trade disputes, as industrial research and pre-competitive development activities are non-sanctionable forms of government support under WTO rules (Gosens et al., 2015; Hoekman et al., 2005).

\subsubsection{Technical standards}

Mature sectors typically have a well-developed set of technological standards and corresponding systems of certification. Such standards help enable rapid market growth as they 'ensure performance, conformity, and safety of new products and processes' (Allen and Sriram, 2000) and thus reduce technological risks (Bergek et al., 2008). Standards are often globally applicable institutions, although their content is usually initially drafted by the incumbents, whilst firms from latecomer countries are required to conform to these standards in order to compete in global markets (Allen and Sriram, 2000; Yoo et al., 2005).

In formative sectors, such standards may not yet be in place, allowing more influence for firms or public organizations from latecomer countries to influence their content, possibly in ways that favour domestic competencies or designs (Yap and Truffer, 2019). The potential competitiveness benefits associated with global diffusion of domestically determined standards are further a key element of the 'lead market' concept (Beise and Rennings, 2005). 


\section{Table 1. Analytical framework: differences between mature and formative sectors and hypothesized relevance for opportunities for catching up}

\begin{tabular}{|c|c|c|c|c|}
\hline $\begin{array}{l}\text { Sectoral } \\
\text { dimension }\end{array}$ & Mature sector & Formative sector & Tentative indicators & $\begin{array}{l}\text { Hypothesized relevance for opportunities for catching up by latecomer firms } \\
\text { or countries }\end{array}$ \\
\hline Technological & $\begin{array}{l}\text { - Large stocks of } \\
\text { relevant experience } \\
\text { in leading firms and } \\
\text { countries } \\
\text { - Dominant design } \\
\text { with incremental } \\
\text { development }\end{array}$ & $\begin{array}{l}\text { - Limited stocks of } \\
\text { relevant experience in } \\
\text { any firm or country } \\
\text { - Competing, possibly } \\
\text { radically different } \\
\text { designs }\end{array}$ & $\begin{array}{l}\text { - Stocks of patents, } \\
\text { manufacturing output, or } \\
\text { project portfolios } \\
\text { - Relative shares of different } \\
\text { designs in patenting activity or } \\
\text { market demand }\end{array}$ & $\begin{array}{l}\text { - In formative sectors, early leaders will not yet have strongly entrenched } \\
\text { competencies, and latecomer challengers therefore have a more limited } \\
\text { experience gap to overcome } \\
\text { - Early leaders are unlikely to possess or maintain competency leads for } \\
\text { several competing designs, limiting experience gaps with latecomer } \\
\text { challengers } \\
\text { - Technological development tends to be more turbulent In formative } \\
\text { sectors, creating a more difficult environment for early leaders to maintain } \\
\text { competency leads } \\
\text { - The lack of a dominant design and availability of typical latecomer } \\
\text { mechanisms for obtaining foreign technology puts higher demands on } \\
\text { domestic competencies for latecomer challengers }\end{array}$ \\
\hline $\begin{array}{l}\text { Market } \\
\text { demand }\end{array}$ & $\begin{array}{l}\text { - Well-developed } \\
\text { demand in existing } \\
\text { markets with clear } \\
\text { consumer } \\
\text { preferences and } \\
\text { commoditized } \\
\text { offering demand } \\
\text { Cyclic fluctuations } \\
\text { growth flo }\end{array}$ & $\begin{array}{l}\text { - Limited demand in } \\
\text { new growth markets } \\
\text { with demand } \\
\text { preferences largely to } \\
\text { be determined } \\
\text { - Logistic demand } \\
\text { growth pattern }\end{array}$ & $\begin{array}{l}\text { - Level of global demand, } \\
\text { number of national markets, } \\
\text { market segmentation } \\
\text { - Rate of demand growth or } \\
\text { decline }\end{array}$ & $\begin{array}{l}\text { - Demand preferences may shift more rapidly in formative sectors, } \\
\text { generating greater competitiveness for latecomer challengers that } \\
\text { invested in the preferred alternative } \\
\text { - Demand fluctuations are more extreme in formative sectors, creating more } \\
\text { difficulties for early leaders to sustain operations and/or serve all market } \\
\text { demand, creating more opportunities for market entry by latecomer } \\
\text { challengers } \\
\text { - The lack of clearly developed markets and demand preferences creates } \\
\text { uncertainties about future market demand and revenue for investments in } \\
\text { selected technological alternatives }\end{array}$ \\
\hline Institutional & $\begin{array}{l}\text { - Limited impact of } \\
\text { government } \\
\text { interventions on } \\
\text { global sector } \\
\text { - Well-developed set } \\
\text { of standards and } \\
\text { certification for } \\
\text { product design or } \\
\text { performance }\end{array}$ & $\begin{array}{l}\text { - High impact of } \\
\text { government } \\
\text { interventions on global } \\
\text { sector } \\
\text { - No clear standards or } \\
\text { certification for } \\
\text { product design or } \\
\text { performance }\end{array}$ & $\begin{array}{l}\text { - Volume of government created } \\
\text { markets vs global markets, or } \\
\text { volume of government R\&D } \\
\text { expenditure vs global } \\
\text { expenditure } \\
\text { - Number, specificity, and level of } \\
\text { globally recognition of existing } \\
\text { standards and certification } \\
\text { agencies }\end{array}$ & $\begin{array}{l}\text { - In formative sectors, a single government R\&D program or market creation } \\
\text { policy may more substantially benefit the competitiveness of domestic } \\
\text { challengers vs foreign leaders } \\
\text { - In formative sectors, there is more potential to influence global technical } \\
\text { standards, potentially favouring domestic competencies of latecomer } \\
\text { challengers and increasing competitiveness versus early leaders } \\
\text { - The lack of globally accepted standards means there is no target to work } \\
\text { towards, and puts higher demands on levels of domestic development } \\
\text { competencies }\end{array}$ \\
\hline
\end{tabular}




\section{Case study selection and data collection}

The global CSP sector is used to illustrate the framework for windows of opportunity for catching up in formative clean-tech sectors. The case of CSP has much potential for highlighting opportunities for catching up, as a fair number of projects is operational or under construction in both advanced and emerging economies (more in section 4). The case study will focus on Chinese catch-up because of an ongoing, strong shift of the global CSP industry towards China.

Information on (global) sector status was collected from a review of journal articles and industry reports, and global CSP project databases (Lilliestam et al., 2017; SolarPACES/NREL, 2018). Information on Chinese projects was collected from annual industry status reports by the Chinese National Solar Thermal Alliance, and Chinese CSP industry news sites, mostly from CNSTE.org, CSP Focus, and CSP Plaza. These sources were parsed for technical specifications, timelines, and firms involved as suppliers in these projects. Patent data was retrieved from EPO's Patstat database of global patent applications, update of Spring 2018 (EPO, 2018).

This was supplemented with information from interviews with 31 experts from 21 organizations, either Chinese or foreign organizations active in the Chinese market, including developer and EPC companies, equipment manufacturers, government agencies, industry alliance groups, and engineering departments of key universities (details in Appendix A). Interviews took place in two rounds, in October 2018 and April 2019. Interviewees were asked about choices in technological paths, perceived relative competencies of domestic versus foreign competitors, and Chinese contributions to global sector formation and re-alignment.

\section{Concentrated Solar Power: sectoral development and leadership changes}

Concentrated Solar Power (CSP) technologies use mirrors to track the sun and reflect and concentrate its light onto a 'receiver', where it is converted into heat. This heat can be used to produce electrical power with a conventional steam turbine and generator, or as industrial process heat. For further details on the technology, see the review by Zhang et al (Zhang et al., 2013).

CSP is currently more expensive than most other renewables, but has the added benefit that it allows for easy integration of energy storage. Back in 2010, the global average generation costs for CSP were roughly on par with those for solar PV, at around $350 \$ / \mathrm{MWh}$, but the latter has seen a far steeper reduction in costs since then. For CSP projects commissioned worldwide in 2018, the average levelized cost of electricity (LCOE) was 185 
$\$ / M W h$, compared to $85 \$ / M W h$ for PV, $56 \$ / M W h$ for onshore wind, and $127 \$ / M W h$ for offshore wind projects (IRENA, 2019). Although further and substantial reductions in LCOE are expected for CSP in the near future, and although CSP may already be competitive on a LCOE basis in some regions of the world (IRENA, 2019), the key benefit of the technology is the possibility for easy integration of energy storage. Storing heat in thermal storage tanks is substantially cheaper than storage of electricity in batteries (Hameer and van Niekerk, 2015). This creates added value, as it allows the renewable electricity to be dispatched on demand, rather than requiring the grid to accommodate generation of variable renewables. Monetizing this value does require an electricity market design that rewards such characteristics, however, and this is far from common in electricity markets worldwide (Castillo and Gayme, 2014; IRENA, 2017).

At the end of 2020, global operational capacity of CSP stood at circa $6,800 \mathrm{MW}$. The sector has seen three distinct construction boom phases, each with a distinct geographical focus (Figure 1). The nationality of supply chain industries has shifted with each construction phase as well (Figure 2). This supply chain includes CSP-specific component manufacturers; the developer, which is responsible for project organization and financing; and the engineering, procurement and construction (EPC) firms, which coordinate the various specialized engineering companies involved. Such EPC is a demanding task, as a CSP plant is a highly complex system, consisting of many highly specialized subsystems. The reflectors and receivers are key components that typically make up circa 40 to $60 \%$ of the investment in a CSP project, with the remainder for design, construction, boiler and generator, and other smaller specialized CSP components (IRENA, 2012).

The first global wave of construction occurred in the 1980s, when a set of 9 stations was built in California (Figure 1), likely driven by concerns over energy prices and energy security following the global oil crisis (Mathews et al., 2014). These were built by a consortium of US and Israeli firms, making them the earliest leaders in the global CSP sector (Figure 2). This was followed by a 15-year construction hiatus.

Between 2005 and 2015, a renaissance of the sector occurred, with construction of circa 4,500 MW of projects, primarily in Spain and the US. This allowed industry entry and leadership attainment by Spanish firms in particular, whilst German firms came to dominate the market for receivers. Since then, austerity measures have led to strong reductions in Spanish support policies, including in most of its renewable energy tariffs, and Spanish development of CSP has ceased. The short-term nature of support measures in the US, strong 
competition from PV, and permitting difficulties, have made the US a difficult market for CSP as well (Hu and Wu, 2013; Martin, 2016).

Since 2016, a third wave of project activity has started, this time located entirely in emerging economy countries, including China, South Africa, Chile, Morocco and other Middleeastern and North African (MENA) countries. The early leaders from the US and Spain have managed to capture a fair share of the market in these new locations, but have been strongly challenged by latecomers from China in particular. Chinese firms have captured substantial market shares for developer and EPC roles, as well as component manufacturing (figure 2).

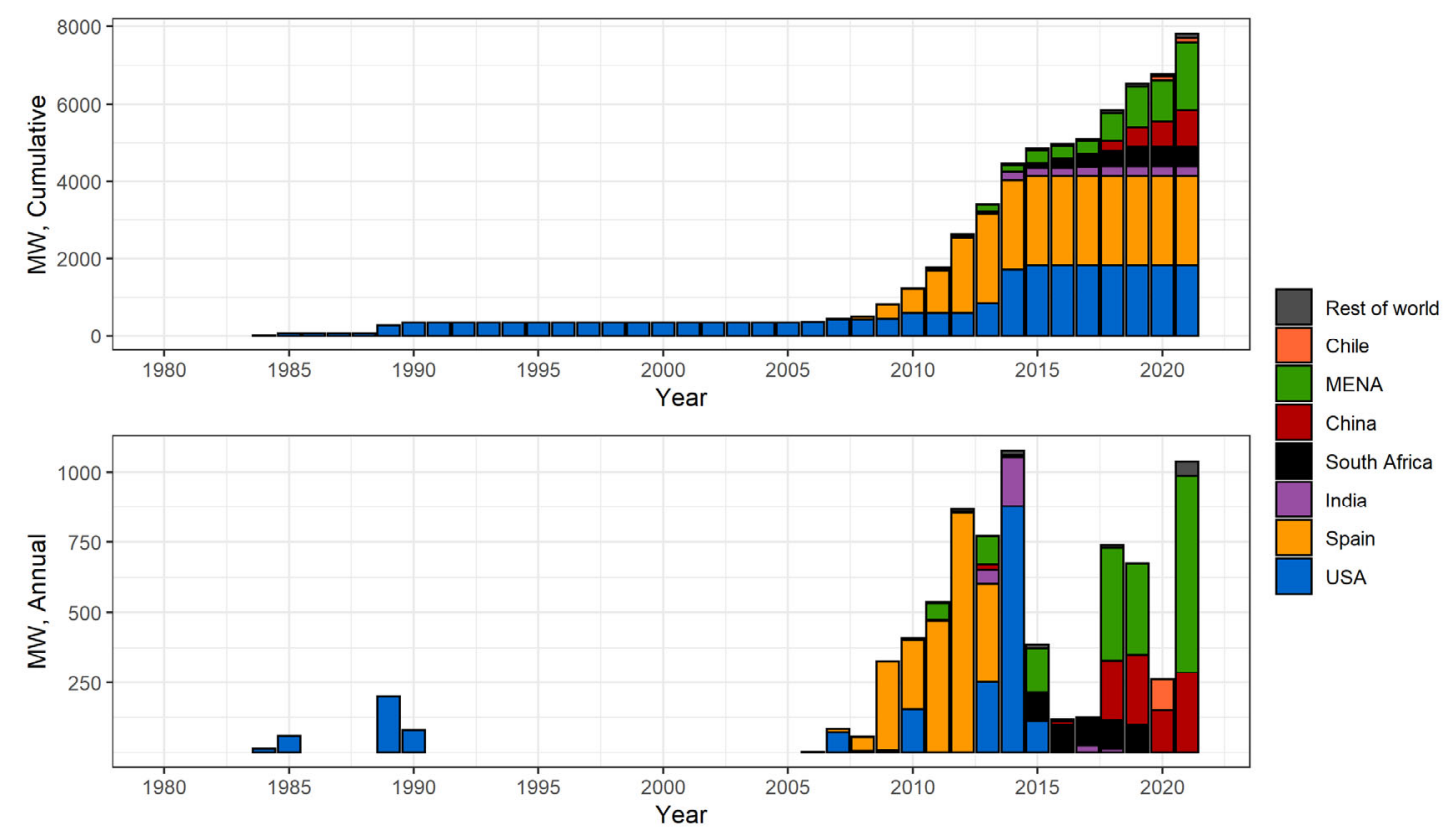

Figure 1. Installed capacity of CSP by project location and year of (expected)

operational start. Cumulative (top), and annual (bottom) capacity (MW). Note data for 2021 includes projects under construction and is subject to change due to further project announcements or cancellations. The statistics in this and other figures include the Yumen SunCan 100MW Molten Salt Tower project and the Delingha SPIC Huanghe 135 MW DSG Tower project, which have shown some sign of project activity in the past few months (CSP Plaza, 2020a, 2020b), but exclude a further 6 Chinese projects ( $460 \mathrm{MW}$ total) which have been under development for some time but which are showing no progress so far and are assessed to be abandoned for now. For further details see the original data sources: (Gosens et al., 2020; Lilliestam et al., 2020b). 

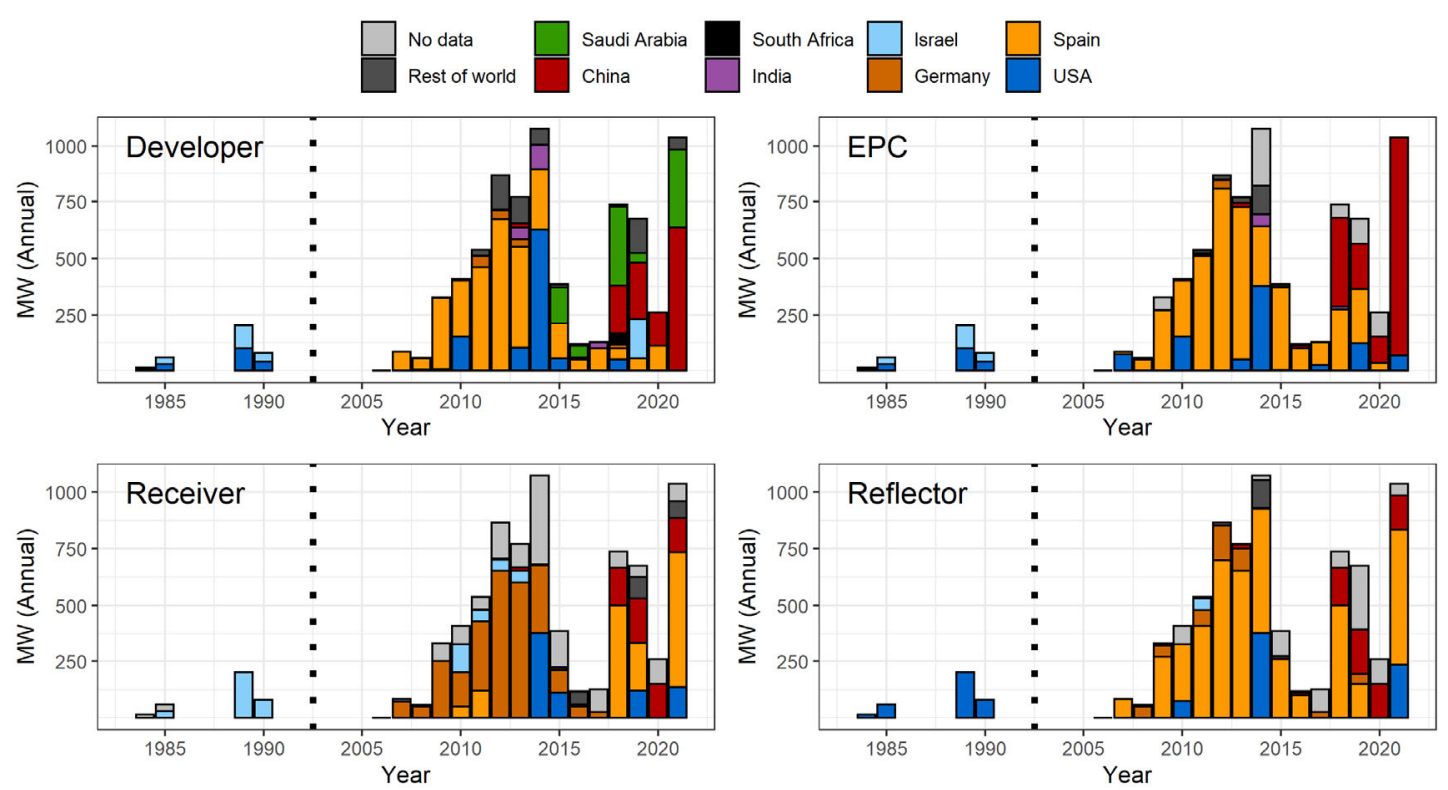

Figure 2. Market shares by CSP project roles and country of origin of firms. Note: projects where a role was shared by firms from multiple countries, market share was weighted accordingly. See also notes with Figure 1. 


\section{The formative nature of the global CSP sector and opportunities for Chinese catching up}

Here we describe the technological, market demand, and institutional dimensions of the CSP sector. For each, we detail whether and how the sector shows signs of being in a formative stage, whether China is catching up, and if the extent or pace of catch-up is due to the formative nature of the sector.

5.1. Formative nature of technologies and opportunities for catching up

The CSP sector lacks a strongly dominant design, early leaders have limited stocks of experience, and several alternative next-generation receiver technologies are being developed concurrently. Limited entrenched competencies of early leaders and a shifting direction of technological development has helped Chinese firms to quickly catch-up.

\subsubsection{Ongoing competition for a dominant design}

CSP technologies come in four varieties: parabolic trough, central tower receiver, linear Fresnel, and dish collectors (Figure 3). Global patenting activity was focused on the parabolic trough design in early periods, but became more diversified in recent years (Figure 4). The share of patents for tower type technologies has grown in particular, reflecting the optimism about future technological improvements and market share of this design (more in section 5.2.1). Note that the sharp drop-off in total patent applications since 2010 is not indicative of a sector-specific crisis. Rather, patenting activity for all climate change mitigation technologies has strongly outpaced growth in overall patenting activity in circa the 10 years leading up to 2010, but has been falling drastically since then (IEA, 2019).

There are important differences in manufacturing skills required for the four designs. The mirrors in tower and Fresnel plants are flat, whilst they are curved in troughs, and even curved in two dimensions in the dish design. The mirrors in trough and Fresnel type plants rotate on a single axis in order to track the movement of the sun, whilst they rotate on two axis in dish and tower type plants, requiring more sophisticated solar tracking and control systems (Zhu and Libby, 2017). Receiver components for trough and Fresnel plants are similar, but differ in concept and materials used with receivers for tower and dish type plants. Manufacturers of different receivers therefore come from different industrial backgrounds, with e.g., a number of specialty glass manufacturers for parabolic trough receivers, and boiler manufacturers for tower type receivers (Gosens et al., 2020; Lilliestam et al., 2017). These different skill requirements mean that leadership in one design does not necessarily result in 
a large experience gap with latecomer challengers in other designs. This creates better opportunities for catching up when market preferences shift.

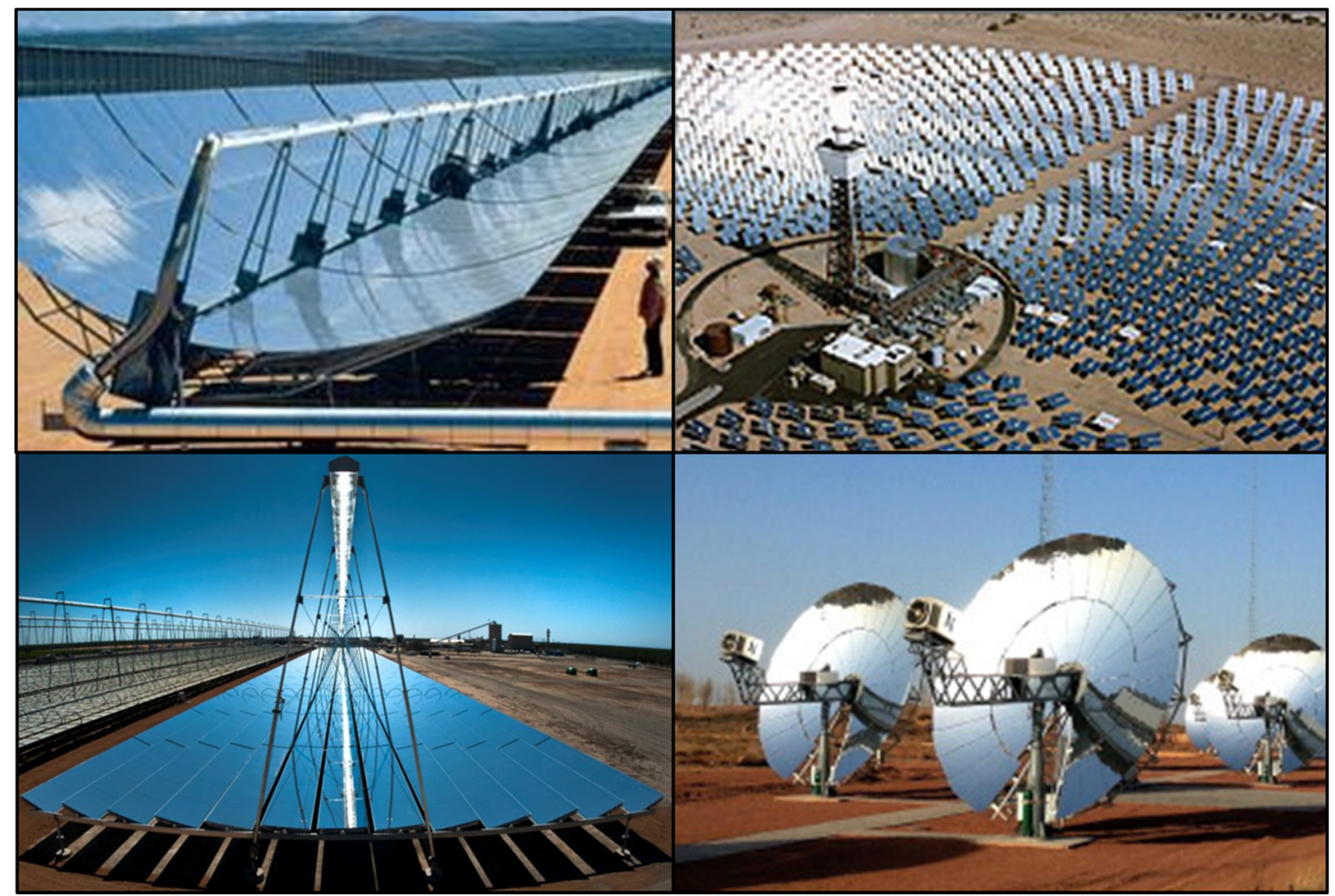

Figure 3. Different designs of Concentrated Solar Power plants. Top left: parabolic trough (Solar Millennium, 2018); top right: central tower receiver (Sandia National Laboratories, 2018); bottom left: linear Fresnel (Laird, 2012); bottom right: Parabolic dish with Sterling engine (Coventry and Andraka, 2017).

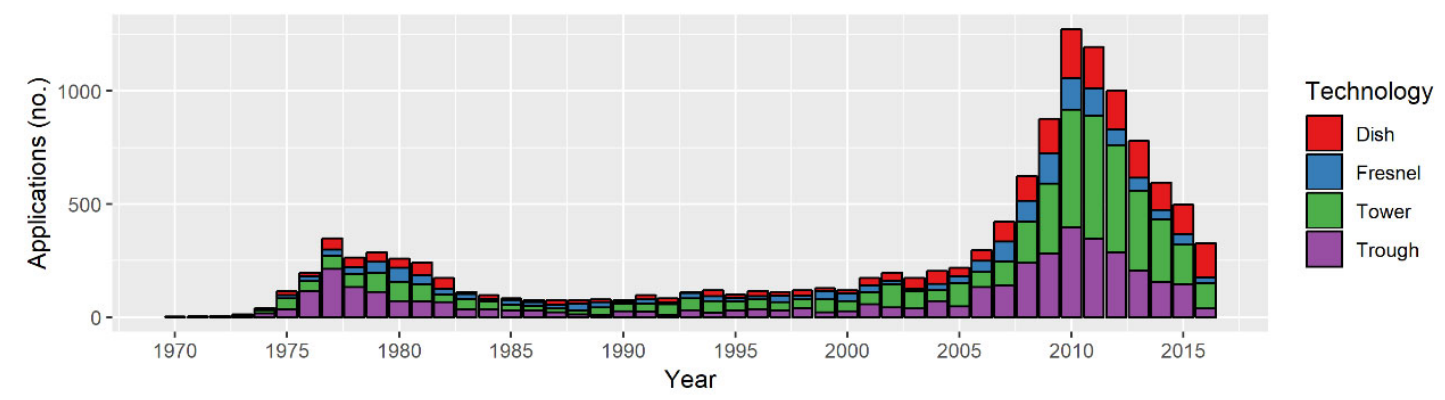

Figure 4. Patent applications, global totals, for different CSP technology types. Data source: (EPO, 2018). 


\subsubsection{Limited stocks of experience}

As the global market is small, early leaders have built up only limited experience with project development, enabling the Chinese industry to catch up with small numbers of projects. The global installed capacity of CSP projects, 6,800 MW by year-end 2020, is equivalent to only $1 \%$ of the global capacity of wind or PV (BP, 2020). With annual global markets generally far below 1,000 MW, even a single utility-scale project represents a substantial market share. This is exacerbated by the segmentation of the market between different designs. China has 7 operational tower type projects of $10 \mathrm{MW}$ or larger, but this seemingly small stock puts it right at the global forefront, as there are only 15 such projects globally (Gosens et al., 2020; Lilliestam et al., 2020b).

Despite the small global market, the number of CSP patent applications is quite substantial. The EPO's patstat database, which covers applications filed across all major patent bureaus worldwide, contains 144,984 'Solar thermal energy' applications, which include CSP, solar hot water, and solar heat pump technologies (EPO, 2018). At least 57,502 are certainly CSP patents, i.e., were labelled with one of the four overall CSP designs, power conversion, or mounting \& tracking (see also Figure 5). This compares to 114,148 wind patents and 214,915 PV patents included in the patstat database. Despite the overall high patent numbers, China has become a substantial contributor to global knowledge development in the CSP sector in recent years (Figure 5). In terms of citations received, China trails the USA, but is on par with other leading nations, i.e., Spain, Germany, Israel, in most CSP technology categories. We use citations received, because patent application numbers are difficult to compare over different national intellectual property offices, in particular when including China (Hu and Jefferson, 2009) (for further methodological details see Appendix B). 


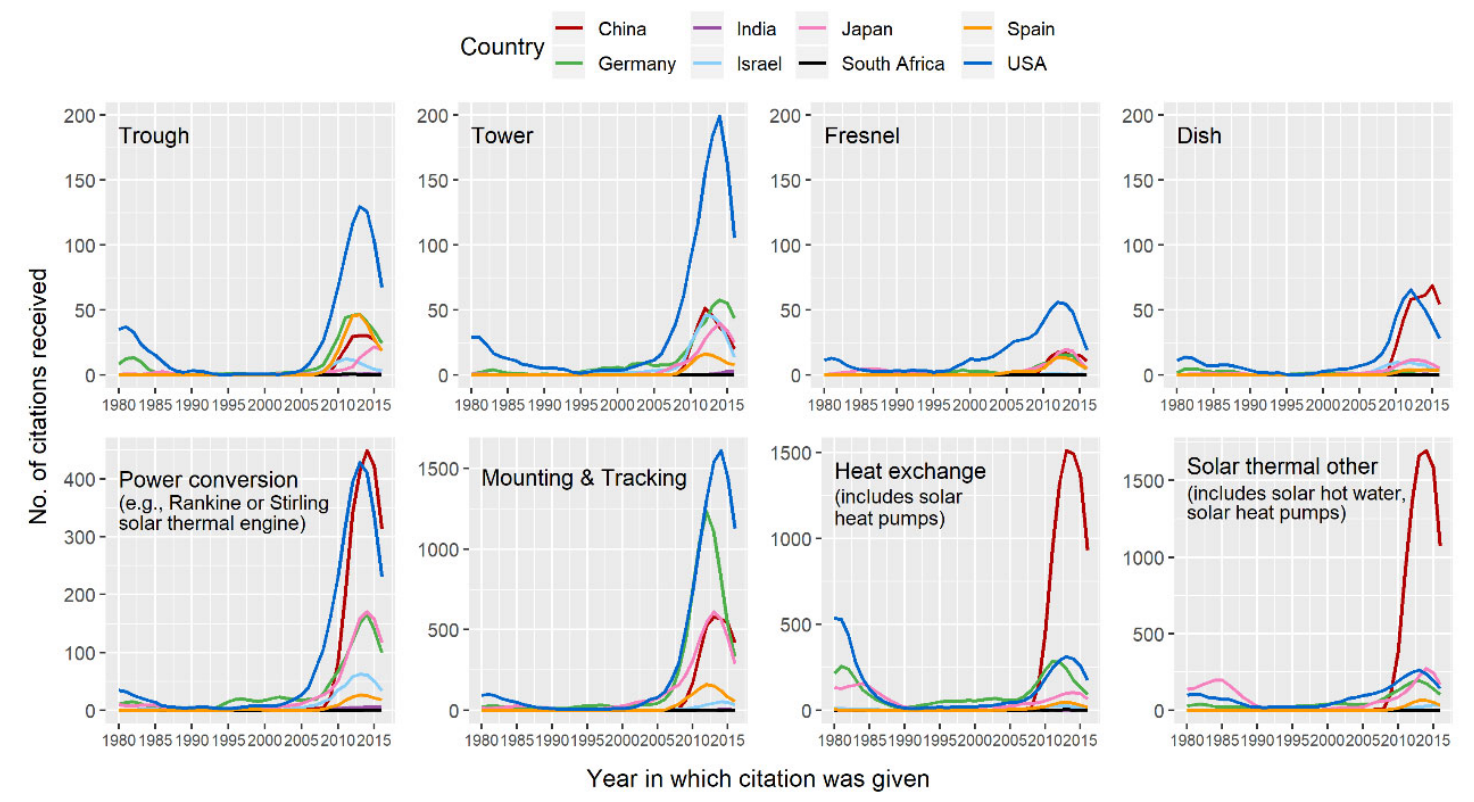

Figure 5. Citations received by solar thermal energy patents, by technology sub-class and country. Measured as 5-year backward citations; for methodological details see Appendix B. Data source: (EPO, 2018). 


\subsubsection{Rapid development of receiver designs}

Several next-generation receiver designs are currently being developed in rapid succession. Such short-cycle technologies are known to be a challenging environment to retain leadership (Lee, 2005). Chinese catch-up is apparent from R\&D and demonstration efforts, which are aimed at both current receiver generations, and at the same nextgeneration designs under development by early leaders.

A key focus in global R\&D efforts for CSP are alternative heat transfer fluids (HTF), which allow higher operating temperatures, which results in higher conversion efficiency and potentially reduced power generation cost. Receiver designs need to be adapted to the choice of HTF and operating temperature (Zhu and Libby, 2017).

The first generation of HTF for use in trough plants include thermal oil and organic HTF, which typically allow temperatures of $350-400^{\circ} \mathrm{C}$ (Zhu and Libby, 2017). For tower type plants, water is the conventional HTF.

A promising alternative HTF is molten salt, which can allow temperatures of $600-700^{\circ} \mathrm{C}$ (Zhu and Libby, 2017). The world's first CSP demonstration project using molten salt was the 20 MW Spanish Gemasolar project, commissioned in 2011. The first Chinese demonstration project to use molten salt, a $10 \mathrm{MW}$ tower type project finished in 2014 , was only the third such project globally. In 2020, a parabolic trough projects using molten salt, currently under construction in China, would be the first such projects worldwide, whilst a Fresnel type project using molten salt, which came online in 2020, was already a world's first (Gosens et al., 2020; Lilliestam et al., 2020b).

Globally, research is ongoing on improved thermal oils and salt types, as well as on several next-generation receivers and HTF types including superheated air, particles, and supercritical $\mathrm{CO}_{2}$, which could allow operating temperatures of 800 to $1000^{\circ} \mathrm{C}$ (Zhu and Libby, 2017). In China, research institutes are similarly working on both current and next-generation technologies (Table 2).

Table 2. HTF research focus by Chinese research institutions

\begin{tabular}{|l|l|}
\hline Research institution & Area of focus \\
\hline Institute of Electric Engineering, CAS & $\begin{array}{l}\text { Oil, water/steam, molten salt, air, particles, } \\
\text { supercritical } \mathrm{CO}_{2}\end{array}$ \\
\hline Zhejiang University & Molten salt, air, particles, supercritical $\mathrm{CO}_{2}$ \\
\hline Tsinghua University & Supercritical $\mathrm{CO}_{2}$ \\
\hline Institute of Engineering Thermophysics, CAS & Supercritical $\mathrm{CO}_{2}$ \\
\hline Beijing University of Technology & Molten salt \\
\hline Shanghai Institute of Ceramics, CAS & Molten salt \\
\hline Sun Yat-Sen University & Molten salt \\
\hline Xi'an Jiaotong University & Water/steam, molten salt \\
\hline
\end{tabular}


Source: (CNSTE, 2017), author interviews.

5.2. Formative nature of market demand and opportunities for catching up

CSP market demand is responding to a number of technological developments, with new market segments opening up where new Chinese entrants face less of an experience gap. Previous market downturns have shaken out many experienced early leaders, and the reputation of remaining leaders has not been established solidly enough to deter Chinese new entrants from entering new global export markets.

\subsubsection{Changing demand for technological configurations}

With a number of new technologies becoming ready for market deployment, CSP markets are undergoing a number of simultaneous shifts in demand preferences. Chinese activities match these trends very well, resulting in quick catching up in these new and most promising market segments, where the early leaders still have limited experience.

The first trend is a change in preferences for overall design, with growing market shares for tower plants, at the expense of trough plants. Second, a change in preferences for heat transfer fluid, with thermal oil or organics being used in most projects up to 2017, whilst circa $40 \%$ of projects from 2018 onwards uses molten salt. Third, an increased demand to incorporate thermal storage, with increasing volumes of storage (Figure 6).

The preferences for tower type projects and molten salt is due to the higher operating temperatures and related efficiency of these technologies (section 5.1.3). Tower type projects are inherently more suited for next-generation HTF, which is a key reason why the IEA considers the outlook for improvement for towers to be 'very significant', and only 'limited' for troughs (IEA, 2010). The preference for thermal storage is because this allows for the electricity to be dispatched on demand. This prevents curtailment, which regularly happens with intermittent renewables, and allows the electricity to be dispatched at times of peaking power demand and power prices (Lilliestam et al., 2018).

The Chinese utility-scale project pipeline (50 MW or more, operational and under construction), strongly reflects expected future global market demand, with 8 molten salt towers and 1 molten salt trough, versus 3 more traditional thermal oil troughs, and 1 linear Fresnel project. All Chinese utility-scale projects are equipped with thermal storage, with an average storage capacity of 8.5 hours (Gosens et al., 2020; Lilliestam et al., 2020b). Most early market leaders have gathered substantial experience in thermal oil trough technology and large-scale thermal storage, but have no or very limited experience with towers or the use of molten salt as a HTF, limiting the experience gap and competitive strength versus latecomer challengers in these promising segments. 

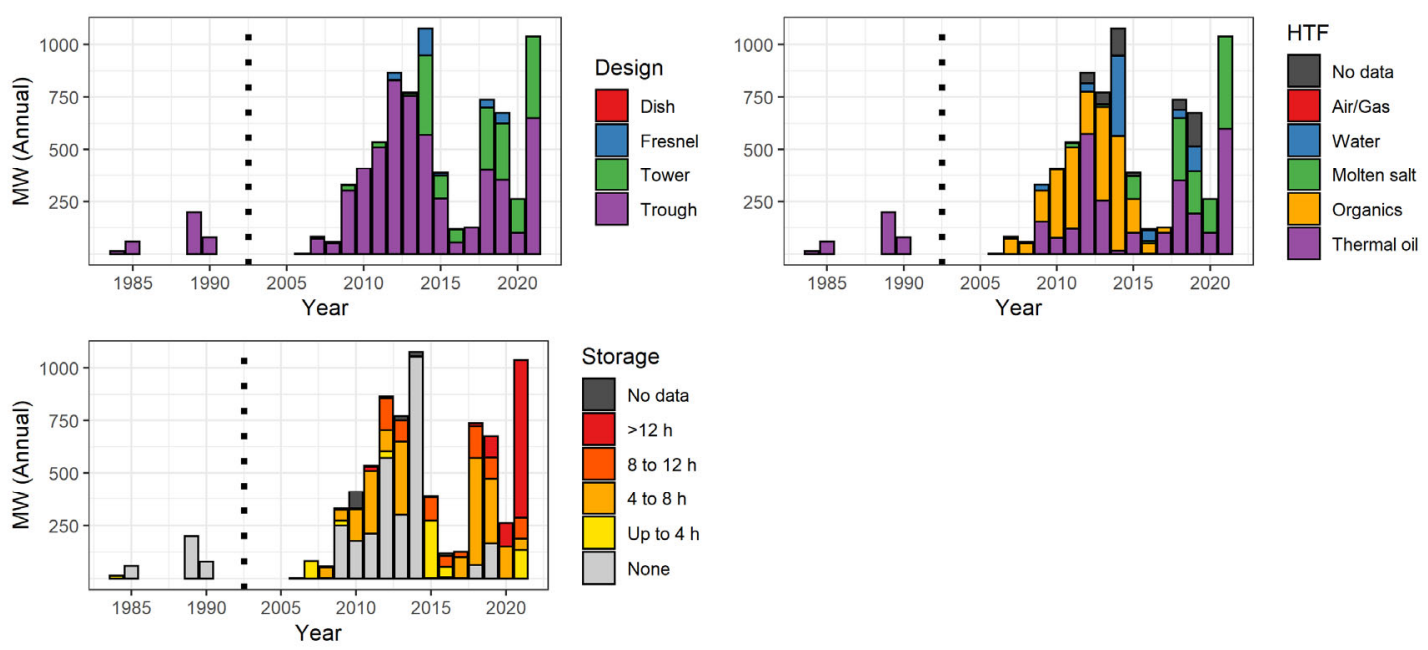

Figure 6. Market size by plant design, Heat Transfer Fluid, and thermal storage size (hours). See also notes with figure 1.

\subsubsection{Demand growth patterns}

Growth periods in the two most important global markets, the US and Spain (Figure 1), have mostly benefitted domestic CSP firms, and further equipment suppliers from Germany and Israel (Figure 2). These two markets have seen drastic downturns, with support policies in Spain faltering due to austerity measures, and a sharp reduction in Investment Tax Credit in the US. These downturns resulted in bankruptcies or industry exits by many of the global lead firms (Table 3), providing room for industry entry by Chinese challengers when global markets picked up again from 2016 onwards. The industry shake-out of experienced lead firms has been particularly strong in the manufacture of parabolic trough receivers. Three receiver manufacturers - SCHOTT, Solel, and Siemens - controlled $98 \%$ of the market until project construction in Spain was halted (Chaanaoui et al., 2016), and all three have since exited the industry (Table 3 ).

Difficulties in forecasting future market growth creates further opportunities for industry entry by latecomer challengers. Five out of seven equipment manufacturers interviewed for this research indicated that they would scale up manufacturing capacity only when orders would come in. Two project developers indicated they could not rely on a single supplier for certain components, as they did not have the production capacity fulfil bulk orders (several 10,000s of a number of key components are needed for a $100 \mathrm{MW}$ project) within the project construction period. This creates opportunities to capture a share of the market by a larger number of new entrants. 
Table 3. Description and fate of major CSP companies

\begin{tabular}{|c|c|c|c|c|c|}
\hline Company & Country & Fate & Year & Description and fate & Sources \\
\hline Luz International Ltd & $\begin{array}{l}\text { US- } \\
\text { Israeli }\end{array}$ & Bankruptcy & 1992 & $\begin{array}{l}\text { Developer of the world's first CSP project, SEGS projects in California in the 1980s. Assets and } \\
\text { technology acquired by Solel }\end{array}$ & (PVNEWS, 2016) \\
\hline Solel & Israel & Acquisition & 2009 & $\begin{array}{l}\text { Design and manufacture of receiver tubes for the world's first CSP project, the SEGS project in } \\
\text { California, and a total portfolio of circa } 600 \mathrm{MW} \text { of projects. Acquired by Siemens }\end{array}$ & (PVNEWS, 2016) \\
\hline Solar Millennium AG & Germany & Bankruptcy & 2011 & $\begin{array}{l}\text { Designer and EPC involved in } 320 \mathrm{MW} \text { of parabolic trough plants in Spain and Egypt. EPC for the } \\
1,000 \mathrm{MW} \text { Blythe station in the US, which was cancelled by the developer. }\end{array}$ & $\begin{array}{l}\text { (SolarPACES/NREL, } \\
\text { 2018) }\end{array}$ \\
\hline Siemens & Germany & CSP industry exit & 2012 & $\begin{array}{l}\text { Entered the industry in 2010, by acquiring Solel. Supplied circa } 320 \mathrm{MW} \text { of projects. Closed down } \\
\text { its CSP activities in 2012, and sold its CSP assets and technology at a steep loss to Rioglass Solar } \\
\text { (Spain) in } 2013\end{array}$ & (Helioscsp, 2013a) \\
\hline Flagsol & Germany & Acquisition & 2013 & $\begin{array}{l}\text { Subsidiary of Solar Millennium. Involved in construction of the earliest Spanish CSP plants. } \\
\text { Acquired by TSK (Spain), although headquarters remain in Germany }\end{array}$ & (Helioscsp, 2013b) \\
\hline SCHOTT Solar & Germany & CSP industry exit & 2014 & $\begin{array}{l}\text { Undisputed leader in the supply of receiver tubes, with a cumulative market share of } 61 \% \text { of all } \\
\text { parabolic trough receivers up to } 2014 \text {. SCHOTT closed receiver tube production in Germany in } \\
2014 \text {, and sold remaining CSP activities to Rioglass Solar (Spain) in } 2016 \text {. }\end{array}$ & $\begin{array}{l}\text { (Chaanaoui et al., } \\
\text { 2016; SCHOTT } \\
\text { Solar, 2014) }\end{array}$ \\
\hline SkyFuel, Inc. & US & Acquisition & 2015 & $\begin{array}{l}\text { Designer and manufacturer of parabolic trough systems. Acquired by Wuhan Kaidi New Energy } \\
\text { (China) in } 2015\end{array}$ & (SkyFuel, 2017) \\
\hline Abengoa & Spain & $\begin{array}{l}\text { Restructuring to } \\
\text { avoid bankruptcy, } \\
\text { sale of CSP assets }\end{array}$ & 2016 & $\begin{array}{l}\text { One of Spain's leading CSP developers. Filed for bankruptcy for its US entities in 2016, and } \\
\text { avoided complete bankruptcy by a large equity for debt deal with its creditors, and raised cash } \\
\text { with sales of } 450 \mathrm{MW} \text { of operational CSP projects and several projects under construction. }\end{array}$ & $\begin{array}{l}\text { (Neumann, 2016; } \\
\text { SeeNews, 2015) }\end{array}$ \\
\hline eSolar & US & Bankruptcy & 2017 & $\begin{array}{l}\text { Developer involved in a long string of projects at home and abroad, most of which never were } \\
\text { completed. Its bankruptcy brought active US developers from } 3 \text { to } 2 \text {. }\end{array}$ & (Deign, 2017) \\
\hline Acciona & Spain & Sale of CSP assets & 2018 & $\begin{array}{l}\text { Large conglomerate with an energy division that mainly develops wind power projects, and one } \\
\text { of Spain's leading CSP developers. Sold five of its six CSP plants in } 2018 \text { to reduce debt. }\end{array}$ & $\begin{array}{l}\text { (New Energy } \\
\text { Update, 2018) }\end{array}$ \\
\hline
\end{tabular}




\subsubsection{Entry in new global markets}

Chinese firms are already finding some demand in export markets (Table 4). Although early leaders remain dominant in export markets, the early success of Chinese firms in export markets, despite their very limited domestic project references, indicates that the global reputation of early leaders has not been very firmly established. This is true for EPC services, but much less so for equipment supply for now (Figure 2).

Shanghai Electric provides EPC services for the world's largest CSP project, a $700 \mathrm{MW}$ project in the United Arab Emirates, even without a domestic track record for CSP projects. According to one industry expert interviewed, the EPC contract did demand a strong track record for the equipment suppliers used, which is why Abengoa was selected to supply and construct the $600 \mathrm{MW}$ parabolic troughs for this project. Shanghai Boiler Works, a subsidiary of Shanghai Electric, will manufacture the receiver for the $100 \mathrm{MW}$ tower in this project, however.

A number of equipment manufacturers interviewed stated they did not expect demand in export markets without domestic reference projects, but initial successes indicate that such requirements are more limited than in mature sectors where incumbents have a more substantial reputation.

Table 4. Chinese activity in foreign CSP projects

\begin{tabular}{|l|l|}
\hline Company & Export market activity \\
\hline SEPCO III & $\begin{array}{l}\text { EPC (shared with Spanish Sener) for the 200 MW NOOR II and 150 MW NOOR III } \\
\text { projects in Morocco (operational) }\end{array}$ \\
\hline Shanghai Electric & EPC for the 700 MW Noor Energy 1 (Dubai) project in the UAE (under construction) \\
\hline Gezhouba \& Supcon & EPC for the $50 \mathrm{MW}$ Minos project in Greece (under development) \\
\hline Shanghai Boiler Works & $\begin{array}{l}\text { Receiver for the } 100 \mathrm{MW} \text { tower of Noor Energy 1 (Dubai), together with Belgian CMI } \\
\text { Solar }\end{array}$ \\
\hline Royaltech & Supplier of over 2,000 receiver tubes to a project in India \\
\hline TRX Solar Tech & Supplier of receiver tubes (amount unclear) to projects in Spain, Middle East and Asia \\
\hline Huiyin Energy & Supplier of receiver tubes (amount unclear) to projects in India and Middle East \\
\hline
\end{tabular}

Sources: www.csp.guru, company websites, (CNSTE, 2017). 
5.3. Formative nature of institutions and opportunities for catching up

Individual countries' policy support schemes can still have substantial impact on global market volume and creation of market demand for domestic industries. Global technical standards are still under development, allowing strong involvement by latecomer country representatives, with potential benefits for domestic industries.

\subsubsection{Impact of domestic market creation policies}

Chinese market creation policies of relatively limited scale created the largest market globally. A Feed-in Tariff (FiT) was initially granted to 23 utility-scale CSP projects with a combined capacity of 1,600 MW (Gosens et al., 2020), and whilst only about $700 \mathrm{MW}$ was completed between 2018 and 2020, this represented about one third of global growth for the same period (Figure 1). Also note that it is quite common for CSP projects to be abandoned after they are announced or even after initial construction start, in foreign markets as well, due to the remaining relatively high financial and technological risk of these projects (Lilliestam et al., 2020a).

The primary market creation policy, which granted a FiT to 20 of the above-mentioned projects, selected 9 tower, 7 trough, and 4 Fresnel projects, demanded at least 4 hours of thermal storage, and allowed only one project of each design in any province (NDRC, 2016; NEA, 2016). According to policy makers interviewed, this was done to determine optimal specifications for domestic projects, but it has simultaneously created a market segmentation that matches future global demand (section 5.2.1), promoting competitiveness of domestic firms in such global markets.

Foreign early leaders have managed to capture only limited shares of the Chinese market, signalling that the reputation of leading firms has not been solidly enough established to strongly outcompete the new Chinese entrants. Importantly, this was achieved despite near absence of market protection measures. Project developers are required to have at least $51 \%$ Chinese ownership, but no such restrictions are placed on firms for design, EPC, or equipment manufacturing roles. There are no CSP-specific import tariffs or domestic content requirements. Still, of the 15 Chinese projects (10 MW+, operational or under construction), 12 used domestic reflector suppliers, and 13 used domestic receiver suppliers (Gosens et al., 2020). This is in strong contrast with e.g., the wind power sector, where experienced foreign manufacturers dominated supply to the Chinese market, until a raft of market protection measures was established (Lewis, 2006).

5.3.2. Impact of domestic R\&D funding policies 
The formative nature of the CSP sector is apparent from the fact that demonstration of next-generation CSP technologies remains strongly dependent on government R\&D funding, even in leading advanced economies.

The EU has ongoing R\&D stimulus programs for CSP aimed at "scaling-up of the most promising technologies to pre-commercial or commercial level" (EC, 2018), and sponsors several MW-scale projects to demonstrate molten salt-based tower technologies, and nextgeneration volumetric air or supercritical $\mathrm{CO}_{2}$ technologies $(E C, 2019,2017)$.

The US 'Sunshot' programme aims to make CSP commercially viable by cutting costs in half by 2030 (U.S. DOE, 2017), and a 'Generation 3 Concentrating Solar Power Systems' R\&D programme to fund $\mathrm{MW}$-scale projects to demonstrate next-generation molten salt types and particle receivers, with the specific aim of operating temperatures of $700^{\circ} \mathrm{C}$ or higher (U.S. DOE, 2018).

In China, both the Institute of Electric Engineering of the Chinese Academy of Sciences and Zhejiang University have government sponsored MW-scale installations to demonstrate molten salt, particle, and supercritical $\mathrm{CO}_{2}$ technologies (see also section 5.1.3). In 2018, an R\&D program funded 18 research organizations and firms to develop particle receiver and supercritical $\mathrm{CO}_{2}$ power generation equipment, for operating temperatures of $700^{\circ} \mathrm{C}$ or higher.

In mature sectors, R\&D programs by latecomer countries typically aim to develop competencies for current generations of technologies already being marketed by incumbents (Lewis and Wiser, 2007). In this formative sector, Chinese government R\&D funds could immediately be aimed at similar generations of technologies under development by early leaders, indicating less substantial effort was required to narrow the gap with the global forefront.

\subsubsection{Development of technical standards and certification}

The formative nature of global technical standards for CSP is apparent from the fact that their development is an ongoing process. The 'Technical committee 117 on solar thermal electric plants' of the International Electrotechnical Commission was established in 2014, and tasked to develop standards for different plant designs and components, most of which are not finished yet (Table 5).

Chinese firms and research organizations are strongly represented in those global CSP standard setting committees, at $18.3 \%$ of a total of 323 members, and even circa $30 \%$ of all members in the sub-committees for whole plant designs (committees 3-1 and 4-1, see Figure 7). This compares to $11.5 \%$ Chinese representatives out of a total of 1340 members working on global wind power standards (IEC, 2019a), and 10.1\% of 1054 members working on global 
solar PV standards (IEC, 2019b), both sectors in which Chinese manufacturers have strong global market shares.

This indicates Chinese catch-up, as global standardization is typically driven by technological leaders (Allen and Sriram, 2000; Yoo et al., 2005). Further, China was the first country to publish a (domestically applicable) design standard for tower type plants, in August of 2018 (CSP Plaza, 2018). This bodes well for continued catching up, as potential diffusion of domestic standards or influence in global standard setting may favor domestic competencies and strengthen Chinese competitiveness (Beise and Rennings, 2005; Yap and Truffer, 2019).

The same could not be said for certification services: all equipment manufacturers interviewed for this research stated that third-party certification was always from foreign certification agencies, usually from the German TÜV or DLR, and that such international certification was requested by foreign and domestic customers alike.

Table 5. List of IEC TC-117 sub-committees on solar thermal electric plants

\begin{tabular}{|l|l|l|}
\hline Task No. & Description & $\begin{array}{l}\text { Publication date } \\
\text { (expected) }\end{array}$ \\
\hline $1-1$ & General Terminology & $02-2018$ \\
\hline $1-2$ & Solar radiation data set for simulations & $11-2017$ \\
\hline $1-3$ & Data format for meteorological data sets & $11-2017$ \\
\hline $2-1$ & Thermal energy storage systems & $03-2020$ \\
\hline $3-1$ & Design of parabolic trough plants & $05-2020$ \\
\hline $3-2$ & Parabolic trough reflector assemblies & $07-2018$ \\
\hline $3-3$ & Parabolic trough receivers & $12-2019$ \\
\hline $4-1$ & Design of solar tower plants & $12-2020$ \\
\hline $5-2$ & Linear Fresnel reflector assemblies & $07-2021$ \\
\hline
\end{tabular}

Source: (IEC, 2019c)

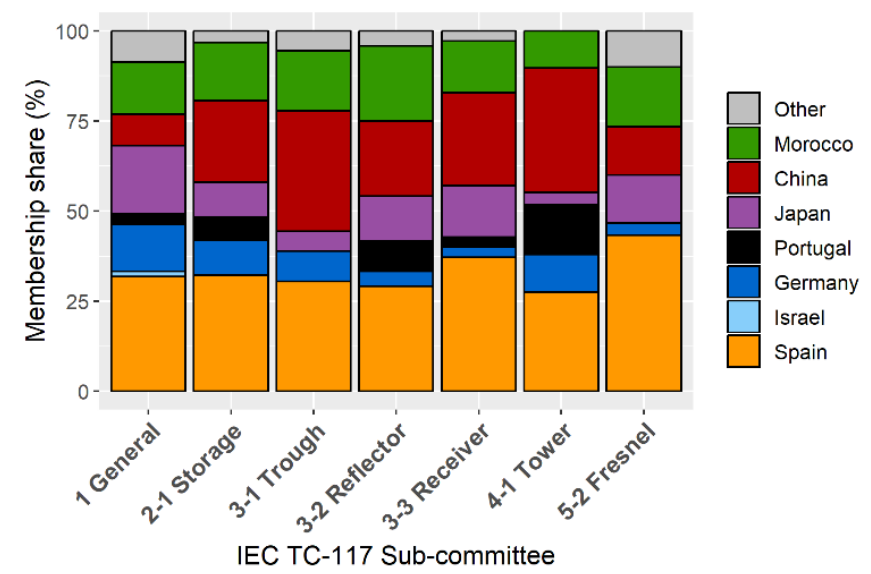

Figure 7. Membership of IEC TC-117 sub-committees by country. Source: (IEC, 2019c). 


\section{Discussion}

Results presented here highlight how the formative stage of a sector may see very turbulent development, with frequent and drastic changes to weakly established technological, market, and institutional dimensions. This creates frequent windows of opportunity for industry entry and catching up, with the drastic changes serving to reduce competence or experience gaps, whilst their weak establishment means that this gap is relatively small to begin with. This turbulent environment creates difficulties for early leaders to retain leadership, and therefore may allow latecomer firms or countries to rapidly reduce or close the gap with global leaders.

Empirically, we show that China has rapidly been catching up with the global forefront in the CSP sector, and that has been due, to a large extent, to the formative nature of the sector. We see clear evidence that China is rapidly closing in on the global forefront in particular based on 1) a rapidly growing share of global number of patents and citations in various CSP sub-fields; 2) a rapid development of experiments and demonstration plants utilizing next-generation receiver and heat transfer fluid technologies; 3 ) a rapidly growing global market share in commercial-scale projects; 4) a market share that is most strongly growing in market segments that are considered to have the best future global market outlook (molten salt towers); 5) an apparent competiveness of Chinese firms in global markets very soon after market entry; and 6) a strong representation in global standard-setting committees, again relatively soon after initial domestic sector formation occurred.

However, the global CSP sector currently still remains in a formative stage, which we have shown to create difficulties for retaining positions of leadership. China's recent relative rise in global leadership rankings in the sector can therefore not be argued to be immune to challenges by future late entrants and continuing, turbulent, sectoral developments. For example, the global market outlook is sunny in particular for molten salt tower type projects with large storage, because of their potential for technical improvements and cost reductions versus competing CSP technologies (Dowling et al., 2017). Chinese firms appear to be relatively competitive in this sub-segment, but this is no strict guarantee for future leadership. The sector still lacks a dominant design, and technological preferences may still shift, in particular as such preferences may be driven by national support schemes, and such schemes continue to be established and abandoned somewhat unpredictably (Lilliestam et al., 2020a). Chinese utility-scale projects further have promising performance (e.g., CSP Focus, 2020) but still lack long-run track records which may still hamper their competitiveness in global markets. Lastly, the fickle nature of CSP support schemes around the world make for a tough market 
outlook for any CSP firm, including the recent Chinese challengers (Lilliestam et al., 2020a). All this is to say that whilst China has rapidly achieved a status as one of the top contenders in the global CSP sector, this may still be a fragile position of relative leadership.

We should also stress that opportunity for catching up does not guarantee catching up. Without effective government policy and/or entrepreneurial strategy to recognize, act on, and utilize these windows of opportunity, there is no reason to assume latecomer firms or countries would automatically catch up. The 'Asian development state', which has regularly been credited as a strong driver for catching up in more mature and conventional manufacturing sectors (Angel and Rock, 2009), may share some characteristics in the deliberative policy making and government-industry coordination that is similarly considered central to the literatures on Technological Innovation Systems or Strategic Niche Management (Bergek et al., 2008; Esarey et al., 2020; Kemp et al., 1998). Further, beyond responding to exogenous windows of opportunity, actors from latecomer environments may actively create these windows through institutional entrepreneurship processes labelled endogenizing windows of opportunity (Yap and Truffer, 2019). The current study contributes to discussions on (predominantly) exogenous factors that may limit or reduce the pace of possible catching up.

Whilst domestic market creation policies are often considered in green industrial policy, and although the Chinese home market was instrumental for domestic firms to develop, we do not believe that China's capability to create a large domestic market was the deciding factor in the relatively strong observed catch-up. Several other emerging economies have created substantial home markets for CSP in the past, without gaining an industry foothold. For other countries with CSP market creation policies, such as India, South Africa, Chile or countries in the MENA region, domestic CSP industry formation was limited to less complex component such as civil works, component assembly, or the manufacture of steel structures and flat mirrors (CORFO \& GIZ, 2019; GIZ \& SASTELA, 2013; Kulichenko and Khanna, 2013). CSP is a highly complex technology, requiring competencies in a wide and diverse set of hightech manufacturing industries, which may be a factor where China exceeds these and other emerging economies. These other latecomer countries may achieve better results in catching up in less technologically complex formative sectors. 


\section{Conclusion}

The Chinese are catching up rapidly in the global CSP sector, with Chinese firms capturing large shares of the market for developers, EPC, and equipment manufacturing in the recent global construction boom. Chinese firms have managed to dominate supply in the domestic market from the very start, and are already beginning to make inroads into global markets. The Chinese are further contributing substantially to R\&D for next-generation technologies, large-scale demonstration of new technological pathways, and global standard setting. This is particularly remarkable as the first domestic market creation policies were enacted as recently as September 2016.

Much of the fast pace of China's fast catching up in the CSP sector could be attributed to the formative nature of the sector, as a number of windows of opportunity were unlikely to have appeared in a more mature sector. Market demand fluctuations have been very extreme, with market demand (nearly) disappearing at two points in time, as the result of policy decisions in just two national markets. The pace of development of next generations of key components, and shifts of technological preferences and market location, were more rapid than would have been likely in a more matured sector. These events have led to drastic industry shake-out of many early leaders, and have complicated retaining leadership for surviving early leaders, thus allowing latecomer challengers to catch up.

These results add to a growing body of literature that investigates how a country's relative comparative advantage in certain technologies or industries is co-determined on one hand endogenously, by deliberative policy making and entrepreneurial strategy, and on the other hand by exogenous factors, such as technological or sectoral characteristics. The implication of this is that effective green industrial policy should likely target industries based on matching country characteristics with technological or sectoral specificities. Whether entering into formative or mature sectors is likely to bring greater economic co-benefits of green industrial policy remains under-investigated and is a matter for follow-up research.

The results also suggest a possibly changing geography of innovation for renewable energy technologies in what has been termed the 'next phase of the energy transition' (Markard, 2018). Beyond mature technologies such as wind and PV genuinely crowding out conventional fossil technologies, this phase will likely also see the development of a number of currently formative clean-tech sectors. Whilst early-stage technological and market development were still the fairly exclusive domain of advanced economies in the first phase of the energy transition, a larger group of increasingly capable emerging and developing economies may be much stronger involved in in such stages going forward. Such new 
competitive dynamics therefore likely ought to be considered in green industry policy strategies in advanced economies as well.

\section{Acknowledgement}

This research was supported by Aalborg University (AAU Grant 771107), and by funding under the Energy Transition Hub at the Australian National University, and a travel grant from the Sino-Danish Center for Education and Research (SDC). These financiers had no involvement in research design or reporting.

\section{CRediT authorship contribution statement}

Jorrit Gosens: Conceptualization, Investigation, Data Curation (Chinese CSP project database), Visualization, Writing - Original Draft, Writing - Review \& Editing; Alina Gilmanova: Investigation, Writing - Review \& Editing; Johan Lilliestam: Data Curation (global CSP project database), Writing - Review \& Editing. 


\section{References}

Abernathy, W.J., Clark, K.B., 1985. Innovation: Mapping the winds of creative destruction. Res. Policy 14, 3-22. Abernathy, W.J., Utterback, J.M., 1978. Patterns of industrial innovation. Technol. Rev. 80, 40-47.

Abramovitz, M., 1986. Catching Up, Forging Ahead, and Falling Behind. J. Econ. Hist. 46, 385486.

Allen, R.H., Sriram, R.D., 2000. The Role of Standards in Innovation. Technol. Forecast. Soc. Change 64, 171-181. https://doi.org/http://dx.doi.org/10.1016/S0040-1625(99)00104-3

Anderson, P., Tushman, M.L., 1990. Technological discontinuities and dominant designs: A cyclical model of technological change. Adm. Sci. Q. 604-633.

Andersson, J., Hellsmark, H., Sandén, B.A., 2018. Shaping factors in the emergence of technological innovations: The case of tidal kite technology. Technol. Forecast. Soc. Change 132, 191-208. https://doi.org/10.1016/J.TECHFORE.2018.01.034

Angel, D., Rock, M.T., 2009. Environmental rationalities and the development state in East Asia: prospects for a sustainability transition. Technol. Forecast. Soc. Change 76, 229-240.

Beise, M., Rennings, K., 2005. Lead markets and regulation: a framework for analyzing the international diffusion of environmental innovations. Ecol. Econ. 52, 5 17. https://doi.org/10.1016/j.ecolecon.2004.06.007

Bento, N., Wilson, C., 2016. Measuring the duration of formative phases for energy technologies. Environ. Innov. Soc. Transitions 21, 95-112. https://doi.org/http://dx.doi.org/10.1016/j.eist.2016.04.004

Bento, N., Wilson, C., Anadon, L.D., 2018. Time to get ready: Conceptualizing the temporal and spatial dynamics of formative phases for energy technologies. Energy Policy 119, 282-293. https://doi.org/10.1016/j.enpol.2018.04.015

Bergek, A., Jacobsson, S., Carlsson, B., Lindmark, S., Rickne, A., 2008. Analyzing the functional dynamics of technological innovation systems: A scheme of analysis. Res. Policy 37. https://doi.org/10.1016/J.RESPOL.2007.12.003

Berkhout, F., Verbong, G., Wieczorek, A.J., Raven, R., Lebel, L., Bai, X., 2010. Sustainability experiments in Asia: innovations shaping alternative development pathways? Environ. Sci. \{\&\} Policy 13, 261-271. https://doi.org/http://dx.doi.org/10.1016/j.envsci.2010.03.010

Binz, C., Anadon, L.D., 2018. Unrelated diversification in latecomer contexts-The emergence of the Chinese solar photovoltaics industry. Environ. Innov. Soc. Transitions. https://doi.org/10.1016/J.EIST.2018.03.005

Binz, C., Gosens, J., Hansen, T., Hansen, U.E., 2017a. Toward Technology-Sensitive Catching-Up Policies: Insights from Renewable Energy in China. World Dev. 96. https://doi.org/10.1016/j.worlddev.2017.03.027

Binz, C., Gosens, J., Yap, X., Yu, Z., 2020. Catch-up dynamics in early industry lifecycle stages - A typology and comparative case studies in four cleantech industries. Ind. Corp. Chang. forthcomin.

Binz, C., Tang, T., Huenteler, J., 2017b. Spatial lifecycles of cleantech industries-The global development history of solar photovoltaics. Energy Policy 101, 386-402.

Binz, C., Truffer, B., 2017. Global Innovation Systems-A conceptual framework for innovation dynamics in transnational contexts. Res. Policy 46, 1284-1298. https://doi.org/10.1016/j.respol.2017.05.012

Binz, C., Truffer, B., Li, L., Shi, Y., Lu, Y., 2012. Conceptualizing leapfrogging with spatially coupled innovation systems: The case of onsite wastewater treatment in China. Technol. Forecast. Soc. Change 79, 155171. https://doi.org/10.1016/j.techfore.2011.08.016

BNEF, 2021. Energy Transition Investment Hit $\$ 500$ Billion in 2020 - For First Time [WWW Document]. URL https://about.bnef.com/blog/energy-transition-investment-hit-500-billion-in-2020-for-first-time/ (accessed 1.19.21).

Boschma, R., Capone, G., 2015. Institutions and diversification: Related versus unrelated diversification in a varieties of capitalism framework. Res. Policy 44, 1902-1914. https://doi.org/10.1016/J.RESPOL.2015.06.013

Boschma, R., Coenen, L., Frenken, K., Truffer, B., 2017. Towards a theory of regional diversification: combining insights from Evolutionary Economic Geography and Transition Studies. Reg. Stud. 51, 31-45. https://doi.org/10.1080/00343404.2016.1258460

BP, 2020. Statistical Review of World Energy 2019 [WWW Document]. URL https://www.bp.com/en/global/corporate/energy-economics/statistical-review-of-world-energy.html (accessed 6.2.20).

BP, 2018. Statistical Review of World Energy 2018.

Castillo, A., Gayme, D.F., 2014. Grid-scale energy storage applications in renewable energy integration: A survey. Energy Convers. Manag. 87, 885-894. https://doi.org/10.1016/J.ENCONMAN.2014.07.063

Chaanaoui, M., Vaudreuil, S., Bounahmidi, T., 2016. Benchmark of Concentrating Solar Power Plants: Historical, Current and Future Technical and Economic Development. Procedia Comput. Sci. 83, 782-789. https://doi.org/https://doi.org/10.1016/j.procs.2016.04.167

Chandy, R.K., Tellis, G.J., 2000. The incumbent's curse? Incumbency, size, and radical product innovation. J. Mark. 64, 1-17.

CNSTE, 2017. Blue Book for Industry Development of Chinese Concentrated Solar Power and Solar Heating in 2016. 
CORFO \& GIZ, 2019. Local Content in CSP/CST Projects: Assessment of the Chilean Industry. Presentation at the 24th Solarpaces Conference, 2-5 October 2018, Casablanca, Morocco.

Coventry, J., Andraka, C., 2017. Dish systems for CSP. Sol. Energy 152, 140-170. https://doi.org/10.1016/J.SOLENER.2017.02.056

CSP Focus, 2020. China Supcon Delingha 50MW CSP plant achieved record high performance in Feb. 2020 [WWW Document]. URL http://www.cspfocus.cn/en/market/detail_2697.htm (accessed 1.12.21).

CSP Plaza, 2020a. Yumen SunCan 100MW molten salt tower solar thermal power generation project is steadily advancing construction [Original in Chinese] [WWW Document]. URL http://www.cspplaza.com/article18913-1.html (accessed 1.12.21).

CSP Plaza, 2020b. The Zhejiang Institute of China Energy Construction won the bid for Qinghai Delingha 135MW Tower CSP Project Survey and Design [Originla in Chinese] [WWW Document]. URL http://www.cspplaza.com/article-18372-1.html (accessed 1.3.21).

CSP Plaza, 2018. The World's First Tower-Type CSP Design Standard Officially Released.

de la Tour, A., Glachant, M., Ménière, Y., 2011. Innovation and international technology transfer: The case of the Chinese photovoltaic industry. Energy Policy 39, 761-770. https://doi.org/10.1016/j.enpol.2010.10.050

de Rassenfosse, G., Dernis, H., Guellec, D., Picci, L., van Pottelsberghe de la Potterie, B., 2013. The worldwide count of priority patents: A new indicator of inventive activity. Res. Policy 42, 720-737. https://doi.org/10.1016/J.RESPOL.2012.11.002

Deign, J., 2017. Concentrated Solar Power Contender ESolar Goes AWOL. Greentech Media.

Dewald, U., Truffer, B., 2011. Market formation in technological innovation systems-diffusion of photovoltaic applications in Germany. Ind. Innov. 18, 285-300.

Dowling, A.W., Zheng, T., Zavala, V.M., 2017. Economic assessment of concentrated solar power technologies: A review. Renew. Sustain. Energy Rev. 72, 1019-1032.

EC, 2019. H2020 projects in the "Solar Energy" field.

EC, 2018. Solar energy - Summary of raodmaps - SETIS - Strategic Energy Technologies Infromation System.

EC, 2017. Initiative for Global Leadership in Concentrated Solar Power -- Implementation Plan.

Ember Climate, 2020. Global electricity review.

EPO, 2018. Patstat online database version of Spring 2018.

Esarey, A., Haddad, M.A., Lewis, J.I., Harrell, S., 2020. Greening East Asia: The Rise of the Eco-developmental State. University of Washington Press.

Garud, R., Karnøe, P., 2003. Bricolage versus breakthrough: distributed and embedded agency in technology entrepreneurship. Res. Policy 32, 277 300. https://doi.org/10.1016/s0048-7333(02)00100-2

Geels, F.W., 2002. Technological transitions as evolutionary reconfiguration processes: a multi-level perspective and a case-study. Res. Policy 31, 12571274.

Geels, F.W., Sovacool, B.K., Schwanen, T., Sorrell, S., 2017. Sociotechnical transitions for deep decarbonization. Science (80-. ). https://doi.org/10.1126/science.aao3760

Gereffi, G., Humphrey, J., Kaplinsky, R., Sturgeon*, T.J., 2001. Introduction: Globalisation, value chains and development. IDS Bull. 32, 1-8.

Gerschenkron, A., 1962. Economic backwardness in historical perspective: a book of essays. Belknap Press of Harvard University Press Cambridge, MA.

GIZ \& SASTELA, 2013. Assessment of the localisation, industrialization, and job creation potential of CSP infrastructure projects in South Africa - A 2030 vision for CSP.

Gosens, J., Binz, C., Lema, R., 2020. China's role in the next phase of the energy transition: Contributions to global niche formation in the Concentrated Solar Power sector. Environ. Innov. Soc. Transitions 34, 61-75. https://doi.org/10.1016/j.eist.2019.12.004

Gosens, J., Lu, Y., 2013. From lagging to leading? Technological innovation systems in emerging economies and the case of Chinese wind power. Energy Policy 60, 234-250. https://doi.org/10.1016/j.enpol.2013.05.027

Gosens, J., Lu, Y., Coenen, L., 2015. The role of transnational dimensions in emerging economy "Technological Innovation Systems" for clean-tech. J. Clean. Prod. 86, 378-388. https://doi.org/10.1016/j.jclepro.2014.08.029

Gosens, J., Lu, Y., Coenen, L., 2014. The Role of Transnational Dimensions in Emerging Economy Technological Innovation Systems for Clean-Tech. J. Clean. Prod.

Grin, J., Rotmans, J., Schot, J., 2010. Transitions to sustainable development: new directions in the study of long term transformative change. Routledge.

Hameer, S., van Niekerk, J.L., 2015. A review of large-scale electrical energy storage. Int. J. energy Res. 39, 11791195.

Hekkert, M.P., Suurs, R.A.A., Negro, S.O., Kuhlmann, S., Smits, R.E.H.M., 2007. Functions of innovation systems: A new approach for analysing technological change. Technol. Forecast. Soc. Change 74, 413432. https://doi.org/10.1016/j.techfore.2006.03.002

Helioscsp, 2013a. Abengoa has bought Siemens' concentrated solar power (CSP) assets through its subsidiary Rioglass Solar.

Helioscsp, 2013b. TSK reinforces its leadership Concentrated Solar Power (CSP) buying German Flagsol.

Hillman, K.M., Suurs, R.A.A., Hekkert, M.P., Sanden, B.A., 2008. Cumulative causation in biofuels development: a 
critical comparison of the Netherlands and Sweden. Technol. Anal. Strateg. Manag. 20, 593612. https://doi.org/10.1080/09537320802292826

Hoekman, B.M., Maskus, K.E., Saggi, K., 2005. Transfer of technology to developing countries: Unilateral and multilateral policy options. World Dev. 33, 1587 1602. https://doi.org/10.1016/j.worlddev.2005.05.005

Hu, A.G., Jefferson, G.H., 2009. A great wall of patents: What is behind China's recent patent explosion? J. Dev. Econ. 90, 57-68. https://doi.org/http://dx.doi.org/10.1016/j.jdeveco.2008.11.004

Hu, M.-C., Wu, C.-Y., 2013. Concentrating Solar Power - China's New Solar Frontier. Asia-Pacific J. 11, 1-11.

Huenteler, J., Schmidt, T.S., Ossenbrink, J., Hoffmann, V.H., 2016. Technology life-cycles in the energy sector Technological characteristics and the role of deployment for innovation. Technol. Forecast. Soc. Change 104, 102-121. https://doi.org/10.1016/j.techfore.2015.09.022

Hussain, A., Arif, S.M., Aslam, M., 2017. Emerging renewable and sustainable energy technologies: State of the art. Renew. Sustain. Energy Rev. 71, 12-28.

IEA, 2019. Global patent applications for climate change mitigation technologies - a key measure of innovation are trending down.

IEA, 2010. Technology Roadmap - Concentrating Solar Power. Paris.

IEC, 2019a. TC 88 Wind energy generation systems.

IEC, 2019b. TC 82 Solar photovoltaic energy systems.

IEC, 2019c. TC 117 Solar thermal electric plants.

IRENA, 2019. Renewable power generation costs in 2018. Abu Dhabi.

IRENA, 2017. Adapting market design to high shares of variable renewable energy. Abu Dhabi.

IRENA, 2012. Concentrating Solar Power -- RENEWABLE ENERGY TECHNOLOGIES: COST ANALYSIS SERIES.

Jaffe, A.B., De Rassenfosse, G., 2017. Patent citation data in social science research: Overview and best practices. J. Assoc. Inf. Sci. Technol. 68, 1360-1374.

Kemp, R., Schot, J., Hoogma, R., 1998. Regime shifts to sustainability through processes of niche formation: The approach of strategic niche management. Technol. Anal. Strateg. Manag. 10, 175195.

Kulichenko, N., Khanna, A., 2013. Development of local supply chain (Vol. 2) : The missing link for concentrated solar power projects in India. Energy Sector Management assistance Program (ESMAP). Washington DC.

Laird, J., 2012. Still on track? Renew. Energy Focus 13, 54-59. https://doi.org/10.1016/S1755-0084(12)70042-X

Lee, J., Bae, Z., Choi, D., 1988. Technology development processes: a model for a developing country with a global perspective. R\{\&\}D Manag. 18, 235-250.

Lee, K., 2005. Making a Technological Catch-up: Barriers and opportunities. Asian J. Technol. Innov. 13, 97-131.

Lee, K., Lim, C., 2001. Technological regimes, catching-up and leapfrogging: findings from the Korean industries. Res. Policy 30, 459-483.

Lee, K., Lim, C., Song, W., 2005. Emerging digital technology as a window of opportunity and technological leapfrogging: catch-up in digital TV by the Korean firms. Int. J. Technol. Manag. 29, 40-63.

Lee, K., Malerba, F., 2017. Catch-up cycles and changes in industrial leadership: Windows of opportunity and responses of firms and countries in the evolution of sectoral systems. Res. Policy 46, 338-351. https://doi.org/10.1016/J.RESPOL.2016.09.006

Lewis, J.I., 2011. Building a national wind turbine industry: experiences from China, India and South Korea. Int. J. Technol. Glob. 5, 281305.

Lewis, J.I., 2006. A Review of the Potential International Trade Implications of Key Wind Power Industry Policies in China. Prepared for the Energy Foundation China Sustainable Energy Program.

Lewis, J.I., Wiser, R.H., 2007. Fostering a renewable energy technology industry: An international comparison of wind industry policy support mechanisms. Energy Policy 35, 18441857. https://doi.org/10.1016/j.enpol.2006.06.005

Lilliestam, J., Barradi, T., Caldés, N., Gomez, M., Hanger, S., Kern, J., Komendantova, N., Mehos, M., Hong, W.M., Wang, Z., Patt, A., 2018. Policies to keep and expand the option of concentrating solar power for dispatchable renewable electricity. Energy Policy 116, 193-197. https://doi.org/https://doi.org/10.1016/j.enpol.2018.02.014

Lilliestam, J., Labordena, M., Patt, A., Pfenninger, S., 2017. Empirically observed learning rates for concentrating solar power and their responses to regime change (with database update of 2018-05-14 from csp.guru/data.html). Nat. Energy 2, 17094.

Lilliestam, J., Ollier, L., Labordena, M., Pfenninger, S., Thonig, R., 2020a. The near- to mid-term outlook for concentrating solar power: mostly cloudy, chance of sun. Energy Sources, Part B Econ. Planning, Policy 119. https://doi.org/10.1080/15567249.2020.1773580

Lilliestam, J., Thonig, R., Gilmanova, A., Zang, C., 2020b. CSP.guru Zenodo data set, version 2020-07-01 [WWW Document]. URL http://doi.org/10.5281/zenodo.4297966 (accessed 1.12.21).

Malerba, F., Nelson, R., 2011. Learning and catching up in different sectoral systems: evidence from six industries. Ind. Corp. Chang. 20, 1645-1675. https://doi.org/10.1093/icc/dtr062

Marchetti, C., Nakićenović, N., 1979. The dynamics of energy systems and the logistic substitution model. PRE24360.

Markard, J., 2018. The next phase of the energy transition and its implications for research and policy. Nat. Energy 1. 
Martin, R., 2016. Ivanpah's Problems Could Signal the End of Concentrated Solar in the U.S., MIT Technology Review.

Mathews, J.A., 2013. The renewable energies technology surge: A new techno-economic paradigm in the making? Futures 46. https://doi.org/10.1016/j.futures.2012.12.001

Mathews, J.A., 2005. Strategy and the crystal cycle. Calif. Manage. Rev. 47, 6-32.

Mathews, J.A., Hu, M.-C., Wu, C.-Y., 2014. Concentrating solar power: a renewable energy frontier. Carbon Manag. 5, 293-308.

Mazzucato, M., 2018. Mission-oriented innovation policies: challenges and opportunities. Ind. Corp. Chang. 27, 803-815.

Michel, J., Bettels, B., 2001. Patent citation analysis. A closer look at the basic input data from patent search reports. Scientometrics 51, 185-201.

Morrison, A., Pietrobelli, C., Rabellotti, R., 2008. Global value chains and technological capabilities: a framework to study learning and innovation in developing countries. Oxford Dev. Stud. 36, 39-58.

Morrison, A., Rabellotti, R., 2017. Gradual catch up and enduring leadership in the global wine industry. Res. Policy 46, 417-430. https://doi.org/10.1016/J.RESPOL.2016.09.007

NDRC, 2016. Notice on solar thermal power generation benchmark tariff policy (English translation).

NEA, 2016. Circular on the construction of solar thermal power generation demonstration projects (English translation).

Nelson, R.R., Winter, S.G., 1982. An Evolutionary Theory of Economic Change. Harvard University Press, Cambridge, Mass.

Neumann, J., 2016. Abengoa Reaches Deal With Creditors to Avoid Bankruptcy. Wall Str. J.

New Energy Update, 2018. European CSP capacity to reach as high as 5 GW by 2030; Acciona sells Spanish plants for $\{\$ 1.34$ billion.

Noailly, J., Shestalova, V., 2017. Knowledge spillovers from renewable energy technologies: Lessons from patent citations. Environ. Innov. Soc. Transitions 22, 1-14. https://doi.org/10.1016/J.EIST.2016.07.004

Pegels, A., Altenburg, T., 2020. Latecomer development in a "greening" world: Introduction to the Special Issue. World Dev. 135, 105084.

Perez, C., Soete, L., 1988. Catching up in technology: entry barriers and windows of opportunity, in: Dosi, G., Freeman, C., Nelson, R., Silverberg, G., Soete, L. (Eds.), Technical Change and Economic Theory. Columbia University Press and Pinter, London and New York.

PVNEWS, 2016. The Delingha project is scheduled to be put into operation in 2016. Can PV be replaced by CSP? (In Chinese).

Quitzow, R., 2015. Dynamics of a policy-driven market: The co-evolution of technological innovation systems for solar photovoltaics in China and Germany. Environ. Innov. Soc. Transitions 17, 126-148.

Reddy, N.M., Zhao, L., 1990. International technology transfer: A review. Res. Policy 19, 285-307.

Rialp, A., Rialp, J., Urbano, D., Vaillant, Y., 2005. The born-global phenomenon: A comparative case study research. J. Int. Entrep. 3, 133-171.

Rodrik, D., 2014. Green industrial policy. Oxford Rev. Econ. Policy 30, 469-491.

Sandia National Laboratories, 2018. Solar Power Tower, PIX 00036.

Schmidt, T.S., Huenteler, J., 2016. Anticipating industry localization effects of clean technology deployment policies in developing countries. Glob. Environ. Chang. 38, 8-20.

Schot, J., Geels, F.W., 2008. Strategic niche management and sustainable innovation journeys: theory, findings, research agenda, and policy. Technol. Anal. \{\&\} Strateg. Manag. 20, 537-554. https://doi.org/10.1080/09537320802292651

SCHOTT Solar, 2014. SCHOTT Solar CSP Repositions its receiver production.

SeeNews, 2015. Abengoa to sell $450 \mathrm{MW}$ of CSP plants to yieldco unit.

Sengers, F., Raven, R., 2015. Toward a spatial perspective on niche development: The case of Bus Rapid Transit. Environ. Innov. Soc. Transitions 17, 166-182. https://doi.org/10.1016/J.EIST.2014.12.003

SkyFuel, 2017. SkyFuel, Inc. announces the future of parabolic trough technology.

Solar Millennium, 2018. Parabolic Trough Power Plants - a Proven Future Technology.

SolarPACES/NREL, 2018. SolarPACES Concentrating Solar Power Projects Database.

Surana, K., Doblinger, C., Anadon, L.D., Hultman, N., 2020. Effects of technology complexity on the emergence and evolution of wind industry manufacturing locations along global value chains. Nat. Energy 1-11.

Tushman, M.L., Anderson, P., 1986. Technological discontinuities and organizational environments. Adm. Sci. Q. 439-465.

Tyfield, D., Ely, A., Geall, S., 2015. Low carbon innovation in China: from overlooked opportunities and challenges to transitions in power relations and practices. Sustain. Dev. 23, 206-216.

U.S. DOE, 2018. Generation 3 Concentrating Solar Power Systems (Gen3 CSP) funding program.

U.S. DOE, 2017. SunShot 2030.

Utterback, J.M., Abernathy, W.J., 1975. A dynamic model of process and product innovation. Omega 3, 639-656. https://doi.org/http://dx.doi.org/10.1016/0305-0483(75)90068-7

van Lente, H., Spitters, C., Peine, A., 2013. Comparing technological hype cycles: Towards a theory. Technol. Forecast. Soc. Change 80, 1615-1628. https://doi.org/10.1016/J.TECHFORE.2012.12.004 
Vasseur, V., Kamp, L.M., Negro, S.O., 2013. A comparative analysis of Photovoltaic Technological Innovation Systems including international dimensions: the cases of Japan and The Netherlands. J. Clean. Prod. 48, 200-210. https://doi.org/http://dx.doi.org/10.1016/j.jclepro.2013.01.017

Vértesy, D., 2017. Preconditions, windows of opportunity and innovation strategies: Successive leadership changes in the regional jet industry. Res. Policy 46, 388-403. https://doi.org/10.1016/J.RESPOL.2016.09.011

Xie, Y., Zhang, C., Lai, Q., 2014. China's rise as a major contributor to science and technology. Proc. Natl. Acad. Sci. 111, 9437-9442.

Yap, X.-S., Truffer, B., 2019. Shaping selection environments for industrial catch-up and sustainability transitions: A systemic perspective on endogenizing windows of opportunity. Res. Policy 48, 1030-1047.

Yoo, Y., Lyytinen, K., Yang, H., 2005. The role of standards in innovation and diffusion of broadband mobile services: The case of South Korea. J. Strateg. Inf. Syst. 14, 323-353. https://doi.org/http://dx.doi.org/10.1016/j.jsis.2005.07.007

Zhang, H.L., Baeyens, J., Degrève, J., Cacères, G., 2013. Concentrated solar power plants: Review and design methodology. Renew. Sustain. Energy Rev. 22, 466-481. https://doi.org/https://doi.org/10.1016/j.rser.2013.01.032

Zhu, G., Libby, C., 2017. Review and future perspective of central receiver design and performance, in: AIP Conference Proceedings. AIP Publishing, p. 30052. 


\section{Appendix A. Details on interviewees}

\begin{tabular}{|c|c|c|}
\hline \# & Organization & Role \\
\hline 1 & Chinese Academy of Sciences & Assoc. Prof. \& CSP project manager \\
\hline 2 & Chinese Academy of Sciences & Professor \& CSP project manager \\
\hline 3 & China National Renewable Energy Centre & Deputy director; Senior industry analyst \\
\hline 4 & CSP industry association & Secretary General \\
\hline 5 & Developer \& Equipment manufacturer A & CEO/founder \\
\hline 6 & Developer \& Equipment manufacturer A & Technical manager \\
\hline 7 & Developer \& Equipment manufacturer B & Vice Chief engineer \\
\hline 8 & Developer \& Equipment manufacturer B & Technology management officer \\
\hline 9 & Developer \& Equipment manufacturer C & Vice general manager \\
\hline 10 & Developer \& Equipment manufacturer D & General Manager \\
\hline 11 & Developer \& Equipment manufacturer E & Engineer \\
\hline 12 & Developer F & Project manager \\
\hline 13 & Energy Research Instiute of the NDRC & Assoc. Research Fellow \\
\hline 14 & Energy Research Instiute of the NDRC & Deputy director; Assoc. Research Fellow \\
\hline 15 & Foreign dish collector manufacturer & General manager \\
\hline 16 & $\begin{array}{l}\text { Foreign tech supplier for steam generation } \\
\text { systems }\end{array}$ & Project and Engineering Director \\
\hline 17 & North China Electric Power University & Professor \& CSP project manager \\
\hline 18 & Receiver tube manufacturer $\mathrm{A}$ & Project manager CSP \\
\hline 19 & Receiver tube manufacturer $\mathrm{A}$ & Project manager high temp tech \\
\hline 20 & Receiver tube manufacturer $\mathrm{B}$ & Engineer \\
\hline 21 & Receiver tube manufacturer $\mathrm{B}$ & Director R\&D Center \\
\hline 22 & Receiver tube manufacturer $\mathrm{B}$ & Deputy general manager \\
\hline 23 & Receiver tube manufacturer $B$ & Foreign business manager \\
\hline 24 & Receiver tube manufacturer $\mathrm{C}$ & Global Director of Sales \\
\hline 25 & Renewable energy industry association & Deputy Secretary General \\
\hline 26 & Renewable energy industry association & Director, policy research \\
\hline 27 & Steam Generation System manufacturer A & President \\
\hline 28 & Technology provider \& consulting agency & CEO \\
\hline 29 & Tsinghua University & Assoc. Prof., Electrical Engineering Dept. \\
\hline 30 & Zhejiang university & Prof., Institute for Thermal Power Engineering \\
\hline 31 & Zhejiang university & $\begin{array}{l}\text { Post-doc, Institute for Thermal Power } \\
\text { Engineering }\end{array}$ \\
\hline
\end{tabular}




\section{Appendix B. Methodological notes on patent statistics used in this paper}

Patent data used in this paper is from PATSTAT Online, version of Spring 2018 (EPO, 2018). We selected all patents tagged with CPC code "Y02 E10/40" for 'Solar thermal energy', including subsidiary classes (see table B.1).

Table B.1 Technology sub-classes in CPC code Y02 E10/40

\begin{tabular}{|l|l|l|}
\hline Technology & Code & Applications \\
\hline Tower concentrators & Y02 E10/41 & 5,406 \\
\hline Dish collectors & Y02 E10/42 & 2,736 \\
\hline Fresnel lenses & Y02 E10/43 & 1,798 \\
\hline Heat exchange systems & Y02 E10/44 & 47,213 \\
\hline Trough concentrators & Y02 E10/45 & 4,491 \\
\hline $\begin{array}{l}\text { Conversion of thermal power into } \\
\text { mechanical power, e.g. Rankine, Stirling } \\
\text { solar thermal engines }\end{array}$ & Y02 E10/46 & 12,274 \\
\hline Mountings or tracking & Y02 E10/47 & 30,797 \\
\hline $\begin{array}{l}\text { Solar thermal other (includes solar hot } \\
\text { water) }\end{array}$ & $\begin{array}{l}\text { Y02 E10/4*, excluding sub-classes } \\
\text { listed separately above }\end{array}$ & 40,269 \\
\hline Solar thermal energy (total) & Y02 E10/4* & 144,984 \\
\hline
\end{tabular}

For international comparisons, we use citation counts rather than application numbers as a proxy for knowledge production. This is because of strong international differences in the propensity to patent, a phenomenon known to bias comparisons with China in particular $\mathrm{Hu}$ and Jefferson, 2009).

Citation practices also differ across patenting authorities, however, with the USPTO in particular requiring more strict inclusion of references to earlier patents (Jaffe and De Rassenfosse, 2017). Michel and Bettels found that applications filed with the USPTO therefore cite circa 3.5 times as many publications as is usual at other national bureaus (Michel and Bettels, 2001). We find a similar difference in our set of CSP patent applications, at least when comparing applications filed with the USPTO with applications filed with the European Patent Office or the World Intellectual Property Organization (Figure B.1). We correct for this by weighting citations given by applications filed with the USPTO with a factor of $1 / 3.5$. Seen the larger difference with other national intellectual property bureaus, some bias towards US patents remains. 

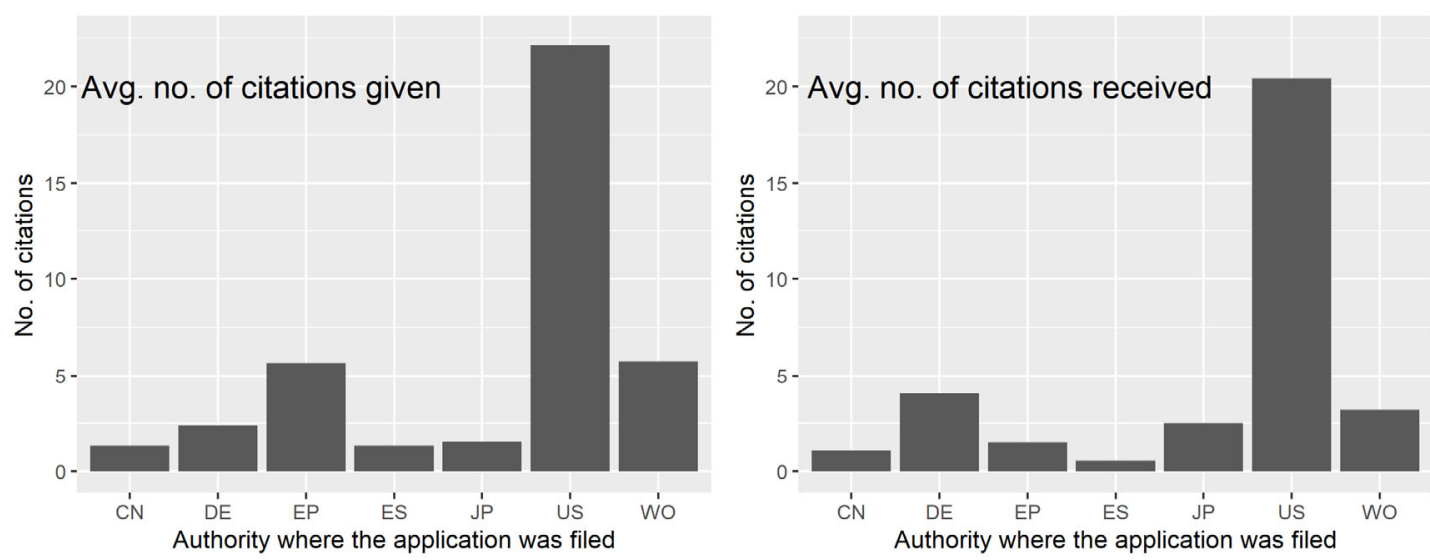

Figure B.1. Average number of citations given (left) and received (right), by authority

where the application was filed (for CSP technology patents).

Determining what country these citations should be counted towards was a five step procedure, based on an implementation of a process as described by De Rassenfosse et al (de Rassenfosse et al., 2013). This process assigns nationality of a patent based on the following order, with each step used only when information for the prior step was missing:

1. Based the country of residence of the inventor(s), weighted in case of multiple inventors;

2. Based on the country of residence of the inventor(s) in applications within the same DOCDB family;

3. Based the country of residence of the applicant(s)

4. Based on the country of residence of the applicant(s) in applications within the same DOCDB family;

5. The nationality of the application authority receiving the application in the first national phase filing within the DOCDB family. Where the first filing was with a supranational bureau such as the EP or WO, the country code within the application number was used.

Lastly, we use 5-year backward citations to measure shifts in useful knowledge production. Patents tend to keep collecting citations over the years, in particular those early patents that defined basic CSP designs. Including all citations to these earlier patents would bias results towards early leaders (Jaffe and De Rassenfosse, 2017; Noailly and Shestalova, 2017). 